\title{
REHABILITATING BECÁN
}

\author{
David Webster (10 ${ }^{\mathrm{a}}$ and Joseph W. Ball ${ }^{\mathrm{b}}$ \\ a Department of Anthropology, The Pennsylvania State University, 409 Carpenter Building, University Park, Pennsylvania 16802 \\ b Department of Anthropology, San Diego State University, 5500 Campanile Drive, San Diego, California 92182
}

\begin{abstract}
Research in 1970 vaulted Becán to prominence on the landscape of great Maya centers. Mapping, excavation, and ceramic stratigraphy revealed that its enigmatic earthwork, first recorded archaeologically in 1934, was a fortification built at the end of the Preclassic period. Large-scale warfare thus unexpectedly turned out to have very deep roots in the Maya lowlands. The site's wider implications remained obscure, however, in the absence of dates and other inscriptions. The ever-increasing dependence on historical and iconographic information in our narratives, along with the invisibility of its Preclassic buildings and plazas, unfortunately marginalized Becán. Some colleagues even claimed that we have misinterpreted both the nature of the earthworks (not fortifications) and their dating (not Preclassic). We rehabilitate Becán by dispelling these claims and by showing that standard archaeological evidence, contextualized in what we know today, has much to say about Becán's role in lowland culture history. We identify intervals of crisis when the earthwork remained useful long after it was originally built, especially during the great hegemonic struggles of the Snake and Tikal dynasties, and introduce new ceramic and lithic data about Becán's settlement history and political entanglements. Our most important message is that inscriptions and iconography, for all their dramatic chronological detail and historical agency, must always be complemented by standard fieldwork.
\end{abstract}

\section{INTRODUCTION}

Becán is one of those big Maya centers that lacks inscriptions, dates, and elaborate iconography. Today such places are frustrating and inconvenient. We call them narrative orphans because they do not neatly dovetail with the historical data, especially from the text-rich, south-central Maya lowlands so central to our current perspectives. Because Becán's early architectural and other features (the earthwork excepted) remain deeply buried, the site does not figure much in the Preclassic literature either. Archaeologists often accordingly ignore such places, or they become ink-blot tests for unidentified sites referred to in the epigraphic record elsewhere (e.g., maybe it is Site X). Here we show that traditional archaeological data can complement dates, inscriptions, and iconography. As a case study we propose new interpretations of central and southern Maya lowlands political history linked to the Tikal/ Kaanu'l hegemonic conflicts.

Fifty years ago research at Becán, Campeche (Figure 1) jumpstarted both our careers as members of the Tulane University/ National Geographic Project. ${ }^{1}$ Our 1970 field season elevated Becán to prominence on the Maya landscape, and justifiably so. ${ }^{2}$

E-mail correspondence to: dxw16@psu.edu

${ }^{1}$ The Tulane/National Geographic effort ran from 1969-1972 under the direction of E. Wyllys Andrews IV, with Richard E.W. Adams as field director. Research extended through 1973 under the continuing direction of Adams, and the aegis of three separate National Geographic and National Science Foundation funded University of Wisconsin and University of Tennessee projects. Principal efforts during that final year included the hillside terracing survey by Turner $(1974,1983)$ and the settlement survey of Thomas (1981).

${ }^{2}$ Earlier surveys before World War I by de Périgny (1909), Merwin, and Hay (Merwin 1913) recorded sites in the region, but somehow missed Becán.
Long before Maya archaeologists became heavily reliant on inscriptions (dates apart), it revealed that Becán was an impressive center in a region seemingly devoid of sites of comparable scale, and one with a deep occupation going back at least to Late Preclassic times, as documented by Ball's (1973) ceramic sequence (Figure 2). Equally revealing was Webster's $(1972,1976)$ investigation of the great earthwork first detected by Ruppert and Denison in $1943 .{ }^{3}$

The fiftieth anniversary of our work presents a timely opportunity to dispel some stubborn misconceptions about the date and function of the earthwork. More important, we reassess Becán in the context of Ball's (2014) revised ceramic sequence (Figure 2), current data about regional settlement, fortifications, warfare patterns, climate change, and the wider culture history of the central and southern Maya lowlands. We discuss new ceramic data that extend the time depth of Becán's occupation, and some implications drawn from Becán's ceramic sequence and its obsidian assemblage about its wider political and military interactions.

Despite its obvious importance, Becán pretty much fell out of view during the interlude between its discovery and the inception of the Tulane/National Geographic Project. Most archaeologists remembered it, if at all, as the biggest center in a region notable for its distinctive Río Bec architecture and for its impressive, if puzzling, earthwork. Unfortunately, they also remembered Ruppert's and Denison's (1943) misnomer for the site—Becán—a Yucatec Mayan word signifying "barranca o cañon formada por agua,"

\footnotetext{
${ }^{3}$ Ruppert and Denison first mapped the site in 1943. They accurately depicted the architecture, but only schematically sketched in the earthwork. Webster added his contours of the earthwork to the architecture shown on Ruppert's and Denison's map (Figure 1). Mexican archaeologists (Campaña 2005) made the most recent and detailed map in 1999-2000 using a total station, but we have no high-resolution image of it.
} 


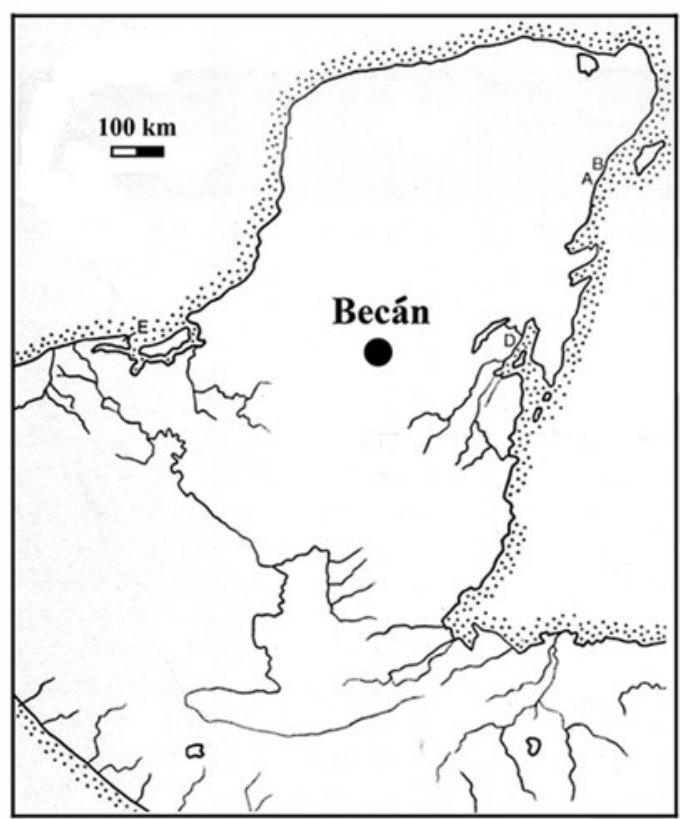

(a)

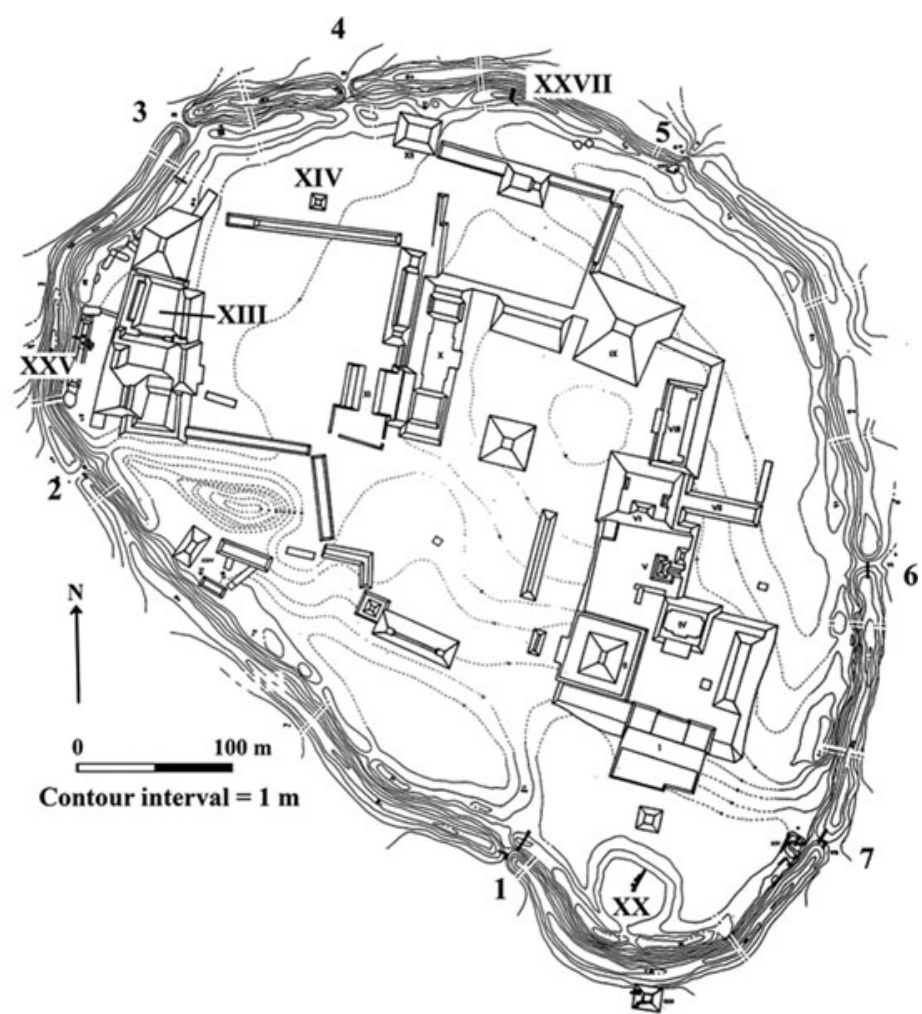

(b)

Figure 1. (a) Location of Becan in the south-central Maya lowlands. Drawing by Webster. (b) Webster's 1970 map of the site. Perimeter numbers show positions of causeways.

that was anglicized into "moat." As we shall see below, this determinative nomenclature, still used today (e.g., Martin 2020:201), has caused decades of confusion. ${ }^{4}$ Morley (1946:319), the most prominent Mayanist of the time, dismissed Becán in his opus The Ancient Maya as a third-rank center. One suspects that the lack of carved and dated monuments explains Morley's neglect because earthwork-enclosed Becán is comparable in scale to the main civic precincts of his beloved Copan (Figure 3).

Before examining some revisionist and recent data about Becán, here is what we knew and did not know in 1970:

(1) We knew almost nothing about Maya fortifications of any date in the central and southern lowlands; the just-discovered Tikal ditch was the only model we had for such features.

(2) We knew a little about a few small but impressive sites around Becán from explorations prior to World War II, but nothing about wider settlement patterns. Archaeologists had even somehow "lost" the famous site of Río Bec B, discovered more than 50 years earlier.

(3) We had no inscribed monuments from Becán, and had they been found, the non-calendrical glyphs could have been read only in the most minimal sense.

(4) There were no monuments from anywhere else nearby with readable dates, emblem glyphs, or other texts.

(5) There was no local or regional ceramic sequence.

(6) There was only a sparse literature on agricultural intensification; the Río Bec region terracing was first published in 1974 and 1983 by Turner.

\footnotetext{
${ }^{4}$ Military engineers call defensive ditches that were never filled with water "dry moats." but this nicety often escapes the average reader (as we well know), who assumes that moats are water barriers.
}

(7) We knew very little about the Preclassic Maya, apart from finds at Tikal and Uaxactun, and almost nothing about the widespread Middle and Late Preclassic florescence and collapse now so well-documented for the central and southern lowlands.

(8) Classic Maya warfare was still a controversial issue, and the time depth of warfare of any kind was unknown.

(9) We had only the slightest inkling of Teotihuacan's intrusions or influence in the lowlands, and incorrectly believed that Teotihuacan had declined as a great Mesoamerican power as late as A.D. 750 .

(10) We knew nothing about the great hegemonic struggles between Tikal and Dzibanche/Calakmul, or that Becán was located in the homeland of the Snake Dynasty.

(11) There was practically no information about lowland climate change or how it might have affected agrarian adaptations, population dynamics, or conflict.

(12) We knew little about lowland Maya lithic industries and obsidian exchange, and nothing about these in the central part of the peninsula.

This is an impressive list of ignorance, some, but not all of which has been dispelled by subsequent research. ${ }^{5}$

\section{THE EARTHWORK}

Despite our general ignorance, there remained the earthwork. Most archaeologists believed that large-scale warfare emerged only in Terminal Classic or Postclassic times, marking a degeneration

${ }^{5}$ For the Río Bec region and southern Campeche in general see the impressive French fieldwork as reported in the Special Section of Ancient Mesoamerica 24, 2013, and the publications by Šprajc summarizing the Slovenian surveys listed. 


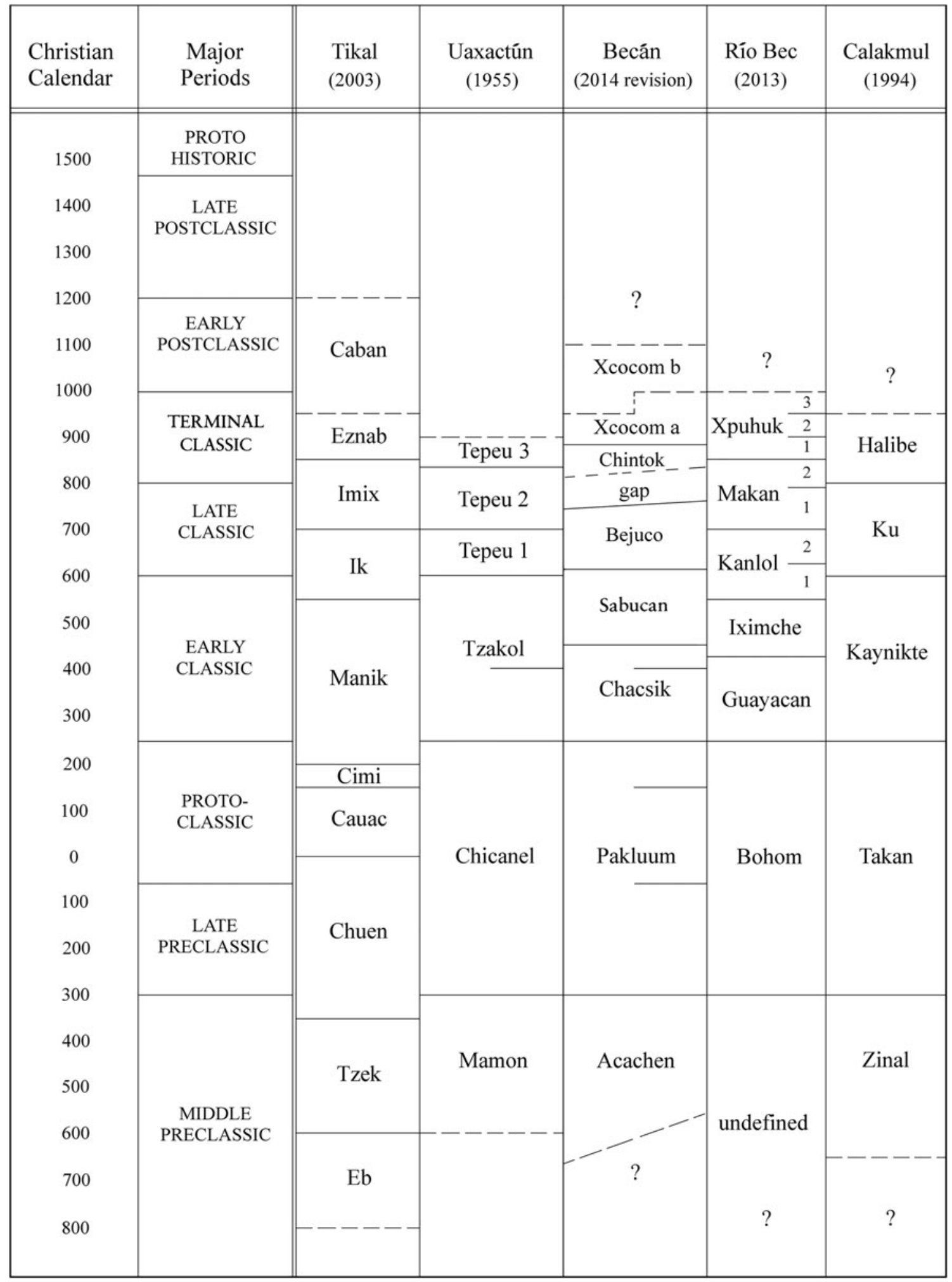

Figure 2. Ball's (2014) Becán ceramic sequence juxtaposed with others from the central and southern lowlands, including the Río Bec region.

from a peaceful and "theocratic" Classic Maya peak under baleful "Mexican" influences. Thompson (1954:106-107) thought the earthwork was indeed a fortification, following an earlier suggestion of Ruppert in his 1943 report, but said that it was never finished because it could not have held water (more about this in the section Water Management or Reservoir). Because he believed serious war was a late aberration, he declared that the earthwork must have been built at the very end of the Classic period. Pollock (1965:395), who shared Thompson's perspective, firmly rejected the moat explanation and said the ditch was just a gigantic 


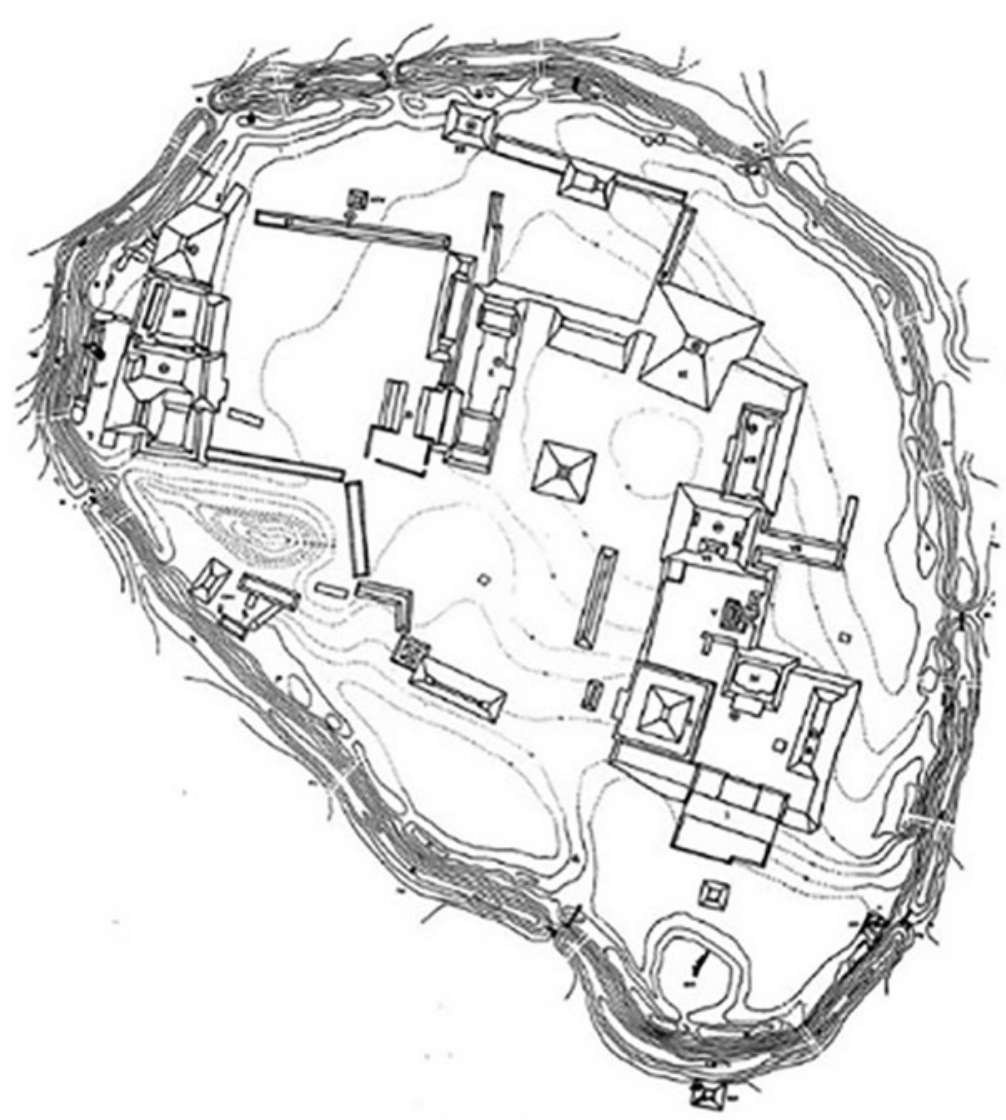

(a)

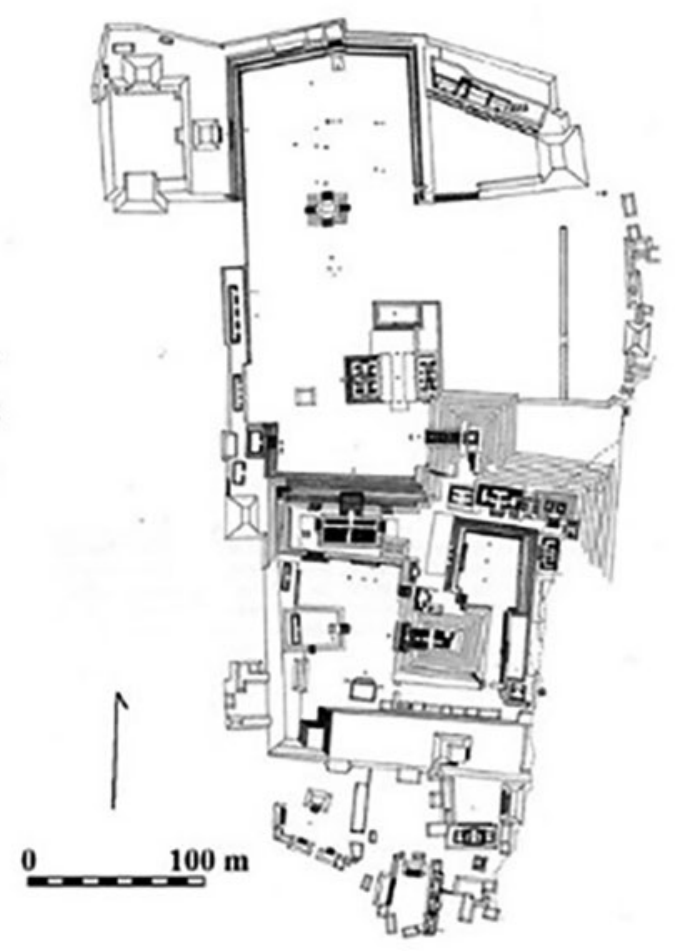

(b)

Figure 3. (a) Becán (drawing by Webster) and (b) Copan shown to the same scale (image by Hasso Hohmann and used with his permission).

borrow pit. Armillas, by contrast, identified the earthwork as a defensive feature and thought that a wooden palisade originally strengthened the inner embankment. He ignored Thompson's claim that the earthwork was never finished, and correctly insisted that "the limestone is very porous and the moat obviously cannot have been filled with water" (Armillas 1951:78). As far as we know, none of these archaeologists visited Becán and carefully inspected the earthwork, but some of their dubious suggestions have proved very intractable, especially the water-barrier presumption. ${ }^{6}$

Our 1970 season provided many insights about Becán's earthwork and its wider implications, and in our dissertations and subsequent publications we made four main claims: (1) the earthwork was a dry ditch and embankment fortification, (2) it was built at the end of the Late Preclassic period, (3) it signaled the presence of largescale warfare at least by that time, and (4) there was evidence that Becán was attacked about A.D. 440-460, probably by Teotihuacan-associated enemies from the Petén. ${ }^{7}$ Within a decade

${ }^{6}$ In 1972, Ball served as driver and guide for a Middle American Research Institute-arranged tour of the southern Quintana Roo-Becán area for a small group of Peabody Museum archaeologists that included Harry E.D. Pollock, Gordon Willey, and Stephen Williams. They visited Kohunlich, Xpuhil, and Becán, but by the time they got to Becán Pollock was weary and his inspection of the site was restricted to the parking area near Causeway 7.

${ }^{7}$ Webster's dissertation dates to 1972 and Ball's to 1973. Both were later published by the Middle American Research Institute in 1976 and 1977 of our research there followed a deluge of revelations from inscriptions at many lowland centers that increasingly marginalized ahistorical Becán in archaeological discourse. Mexican-sponsored research in the 1990s and early 2000s produced new information, building restorations, and a better map, but also, as we shall see shortly, some major revisionist claims (Benevides 2005; Bueno Cano 1999; Campaña 2005, 2014). We accordingly take this opportunity to revisit what we found in 1970, what we thought about it then, and how our ideas have held up or changed.

Our discussion is divided into two main parts. We first reexamine the dating of the earthwork, and then its functions - this by way of necessary rehabilitation. This is old ground, and primarily serves to dispel misconceptions and misrepresentations that somehow persist. The second and most important part builds on information that has emerged since 1970 to place Becán's earthwork and other features within the larger context of the local culture and political history of southern Campeche, and more specifically of the Tikal/Kaanu'l conflicts. Our overview is timely for several reasons. Much has been published in the last 20 years about Maya water-manipulation strategies, of which Becán is a putative early example. Today we also know much more about ancient fortifications. ${ }^{8}$ Ball's (2014) reevaluation

respectively. In this article we cite the later, more accessible, and slightly revised versions.

${ }^{8}$ Levia (2010) provides an excellent and extremely comprehensive overview of Maya fortifications and warfare of all periods and regions. 
of his ceramic sequence identified a major break in continuity in the middle eighth through the early ninth century. This break, coupled with his recent analysis of ceramics recovered by the Slovenian projects in the region, provides a contextually more expansive perspective on the deep occupational history of the earthwork-encircled center and its surroundings, and the political dynamics of the hegemonic conflict between the Tikal/Kaanu'l confederations. ${ }^{9}$ We also present new insights about the political and economic implications of Becán's distinctive obsidian inventory and its Early Classic Sabucan phase ceramics. Finally, we can now identify several episodes of vulnerability-particularly during the Tikal/Kaanu'lwhen Becán's defenses might have proved useful even long after they were originally constructed and maintained.

\section{When Was the Earthwork Built?}

Webster's initial assumption in 1970, influenced by the earlier speculations of Thompson and Pollock, was that defenses like Becán's were products of the breakup of Classic society in the eighth and ninth centuries. This idea turned out to be seriously wrong as excavation progressed and as Ball examined the recovered sherds each day. Our eventual conclusion that the earthwork was instead Late Preclassic was controversial in the early 1970 s, and strangely still is for some. Webster is responsible for a certain chronological sloppiness because in his dissertation he allowed a bit of wiggle-room by putting construction somewhere in the second to the fifth centuries A.D. Ball was then still refining his original ceramic sequence, and in particular dividing the 550-year long Late Preclassic Pakluum complex into shorter facets. He concluded that most Preclassic material at Becán was from late and terminal Pakluum times, or roughly 100 B.C. to A.D. 200, and that the abundant (albeit buried) Preclassic structures, plazas, and other features at the site, including at least one large pyramid exceeding $10 \mathrm{~m}$ in height, were of similar age. So too were the ceramics from the most revealing stratigraphic contexts associated with the earthwork. Ball accordingly argued strongly for a Late Preclassic date of A.D. 100-200 for the defensive system (Ball and Andrews 1978:14) and Webster adopted this reinterpretation, a possibility he had always envisioned (see the preface to the 1976 version of his dissertation and Webster 1977).

When we did our research, the putatively Early Classic Tikal earthwork (Puleston and Callender 1967) was the only comparable feature, and it stimulated interest in Maya warfare, particularly possible conflicts between Tikal and neighboring Uaxactun. ${ }^{10}$ Amidst the dearth of evidence for Preclassic warfare, our Becán earthwork date generated skepticism because it seemed unique. Today we have evidence for Preclassic defenses at Tintal, Xulnal, Holmul, El Mirador, Cival, Punta de Chimino, Macabilero, Muralla de Leon, Cerros, La Cuernavilla, and perhaps at Edzna, Los Naranjos, and Nixtun-Ch'ich', among other places, so Becán is hardly exceptional. ${ }^{11}$ Not only that, but some of these early defenses are

\footnotetext{
${ }^{9}$ Slovenian Academy of Sciences and Arts Archaeological Project in Southeastern Campeche, seasons 2013, 2014, and 2017.

${ }^{10}$ William Rathje once presented an SAA paper in which he suggested that interest in Maya warfare increased during the late 1960s and early 1970s because of the political climate of the Viet Nam war. The reality is more prosaic. Callender stumbled on the Tikal earthwork quite by accident in 1966, and E. Wyllys Andrews IV initiated our Becán project because a decent road had finally been built across the peninsula, not because of the allure of possible insights about Maya warfare.

${ }^{11}$ The chronology of earthworks such as those at Tintal remains poorly understood. Quite possibly they are earlier than the earthwork at Becán and
}

bigger than those built by the Maya during Classic or Terminal Classic times. If we had first argued that Becán's earthwork was Late Preclassic in, say, 1995, no one would have blinked an eye. Nevertheless, we shall see that archaeologists who worked at Becán in the 1980s, 1990s, and 2000s continue to assert, echoing Pollock, that the earthwork is just a gigantic Terminal Classic borrow pit or reservoir, but not on the basis of any new evidence.

We have many clues about chronology, but the most important ones derive from architectural stratigraphy (see Webster [1976] and Ball [1977b] for details). The principal "built" feature of the earthwork is the imposing inner embankment, composed of material thrown up out of the ditch and only along its inner edge (Figures 4 and 5), and in some places directly associated with datable structures.

Structure $X X V$. Most of the embankment fill consists of white, or sometimes grey-brown, sascab with scattered dark streaks of old topsoil in the lower levels. Fortunately for us, this fill covered up an earlier building and built surfaces, and elsewhere was leveled off to serve as foundations for later ones. We examined two such buildings along the northwestern segment of the embankment. The first was Structure XXV (Figures 1 and 6), a 50-m long, well-preserved range structure built atop a flattened-off section of the embankment just behind the imposing palace Structure XIII. Structure XXV is firmly of Late Classic date and is itself underlain by floors dating from A.D. 350 to 650 that were also built atop the old embankment deposits. The latest possible date for the earthwork is thus about A.D. $350 .{ }^{12}$

Structure XXVII. Even better information came from the small Structure XXVII, whose rear wall Webster noticed eroding from the outer slope of the embankment between Causeways 4 and 5 (Figure 1). Although the structure begged for excavation, Adams, codirector of our project, disagreed. We both fondly remember a very public argument Webster had with Adams, who finally admitted that Webster was right, but only from the rational point of view! The rational view won out, and we jointly excavated Structure XXVII. We exposed several buried plaster floors beneath a little Late or Terminal Preclassic (Pakluum) building and its associated plaza surface (Figures 7 and 8). Structure XXVII had been carefully covered with the sterile sascab of the embankment after the Maya removed its roof and upper walls. Although later damaged by root action, much of the building was beautifully preserved, especially its little front façade that retained extensive patches of a single coat of fine, red-painted plaster, and a smooth, almost pristine plaster floor that extended from it to the south. ${ }^{13}$ Both floor and building had been scrupulously, almost reverently, cleaned before they were buried.

might have served as models. If so, Becán is even less unusual. On the other hand, Becán might have served as a model for Tikal, assuming that earthwork is later. The recent Buenavista Valley projects led by Houston and Garrison (IGarrison and Houston 2018a, 2018b) have revealed whole defensive systems just to the west of Tikal. La Cuernavilla is among the largest.

${ }^{12}$ To Richard E.W. Adams's considerable and vociferous annoyance at the "waste" of effort, Ball re-excavated Structure XXV in 1973 to double check these findings, selecting a different room in the five-chamber building for clearing and pitting. He obtained the same results as Webster did in 1970.

${ }^{13}$ Structure XXVII was unusual in that it had only three superstructure walls. The open front façade makes it appear more like a stage than an enclosed room. There might have been some kind of perishable screen that left no traces. 


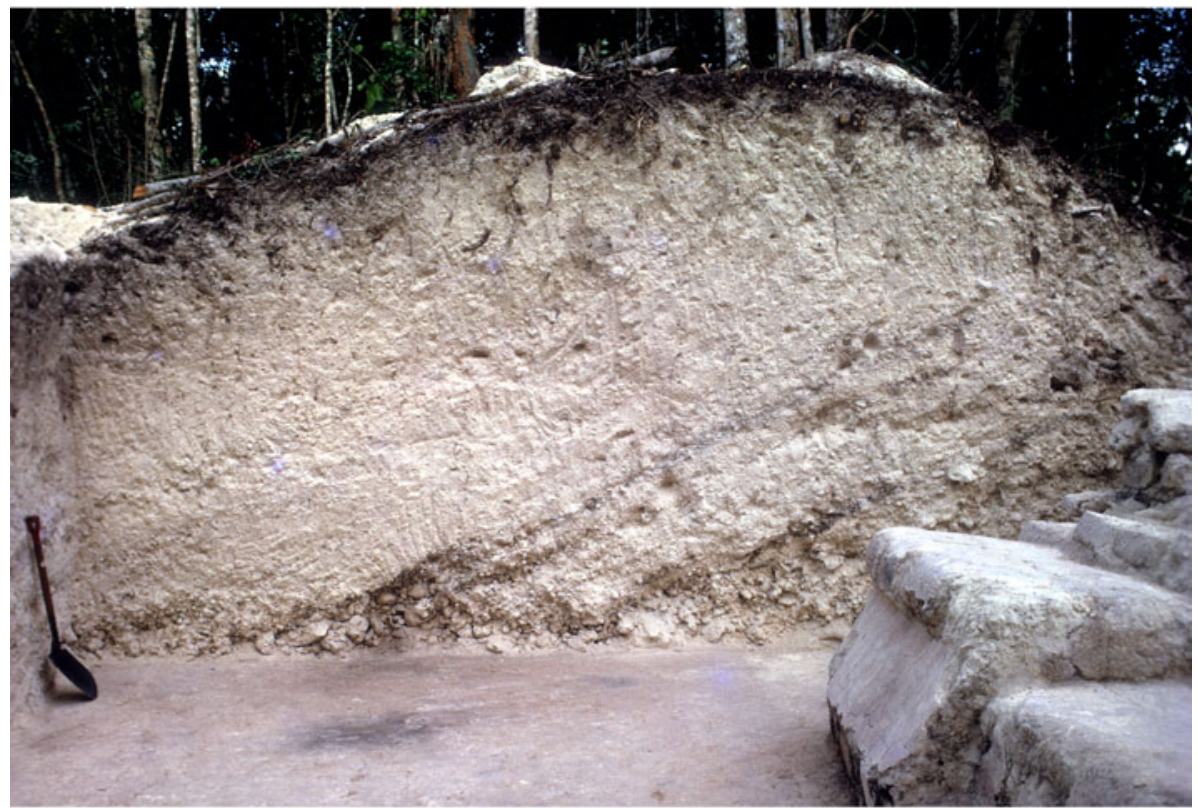

Figure 4. Section through the embankment near Structure XXVII showing white sascab with basal streaks of old topsoil, but no large limestone fragments. Note the beautifully preserved floor in front of the building, which was obviously very clean when buried by the embankment. Photograph by the authors.

All of the identifiable sherds $(\mathrm{n}=1,860)$ from the Operation 13 trenches were of Pakluum or earlier date. Contexts included the embankment deposits covering the building and its associated plaza floor, the fill of that floor and the earlier ones, and the middens beneath them. The rubble core of Structure XXVII produced only 31 sherds, but also an intact Pakluum Usulutan vessel, probably a dedicatory sub-floor cache. Subsequent 1973 excavations below the two floorings that abutted onto and ran beneath Structure XXVII yielded an additional 8,771 sherds, all again of mixed late and early Pakluum or earlier Acachen date. The upper Floor 1 (454 sherds) is emphatically of late Pakluum age, whereas
Floor 2 (8,317 sherds) might have been of earlier Pakluum date with a subfloor core laid directly over and grading into a Middle Preclassic Acachen midden and soil surface immediately overlying bedrock.

Structures XXV and XXVII together create a kind of post quem ante quem stratigraphic sandwich consistent with an early date for the embankment, and by inference the earthwork as a whole. Think about this another way. Imagine that the earthwork had been built at either the beginning or the end of the Late Classic Bejuco ceramic phase (i.e., around A.D. 600 or 750), or even as late as the Terminal Classic. If so, Structure XXVII and its adjacent

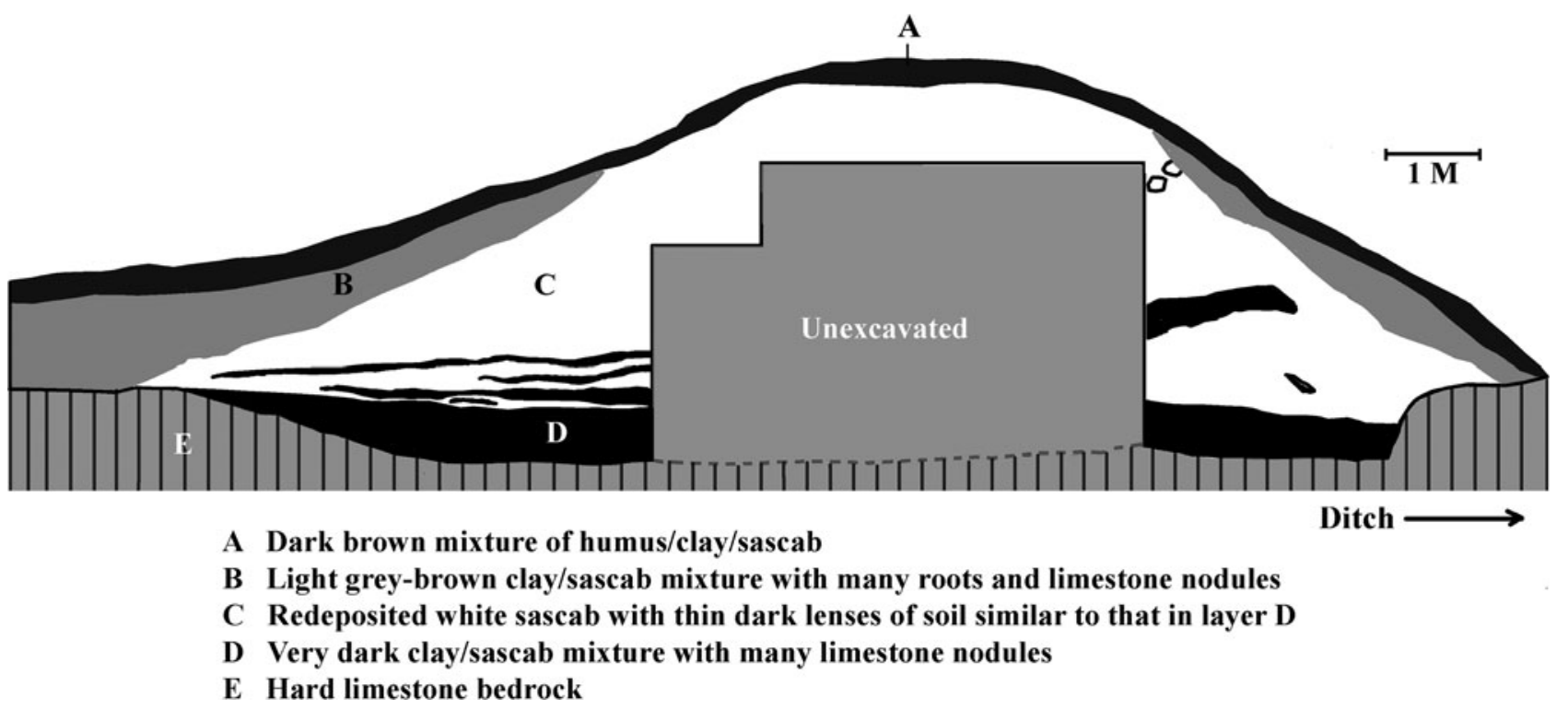

Figure 5. Section through the embankment near Causeway 1. Image by the authors. 

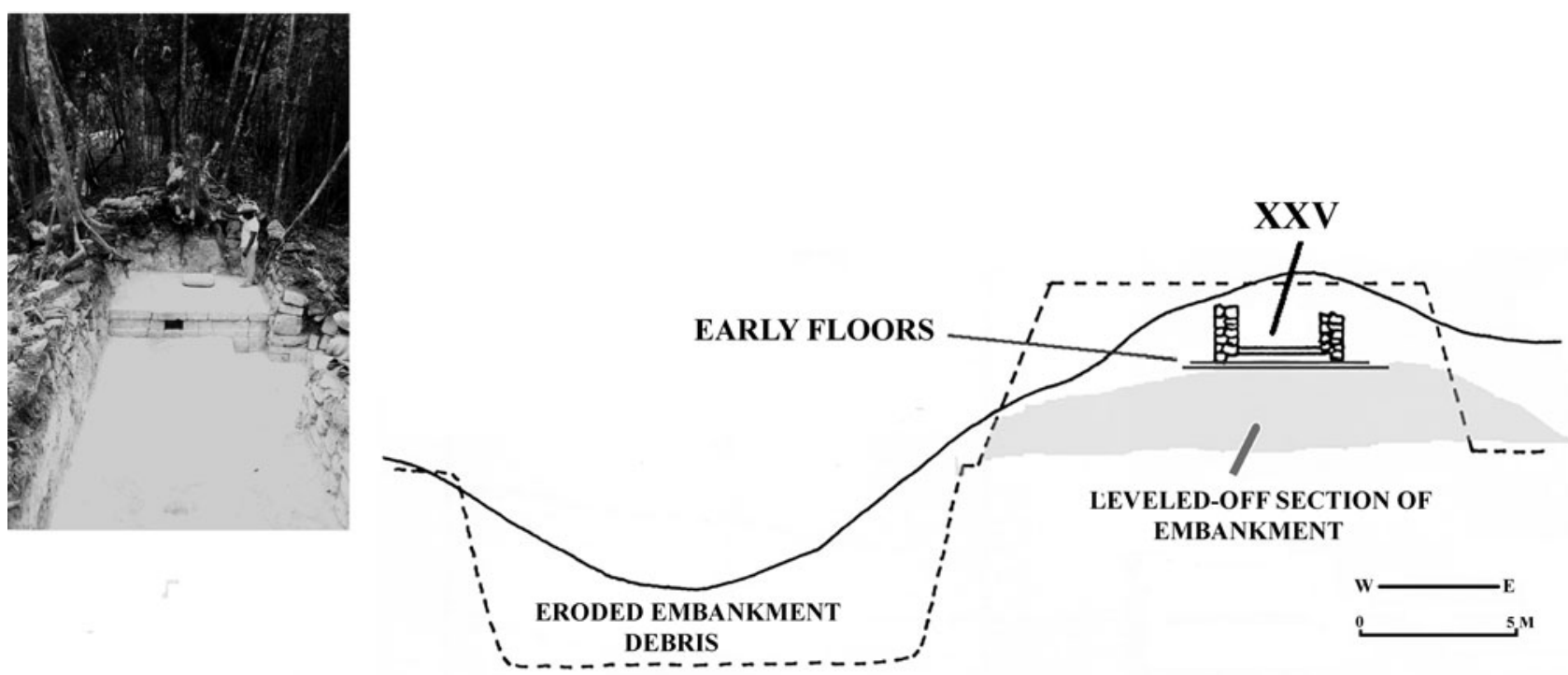

Figure 6. Structure XXV during excavation (left) and schematic drawing of its position in relation to the ditch and embankment. Photograph and image by the authors.

pristine floor somehow stood intact for at least 350 years without seriously deteriorating, without being altered, without being replastered, and without accumulating late sherds and other trash. This is wildly improbable. We reburied Structure XXVII in 1971 because leaving it exposed would have resulted in its rapid destruction. ${ }^{14}$

Artifacts from the Earthwork Components. Other chronological clues came from causeway and embankment excavations and from debris in the ditch. All the causeways originally consisted of a hard limestone caprock underlain by much deeper and softer sascab (Figure 9). The upper sections of two of them had been purposely cut, possibly in the face of some threat, and later repaired. Fill from the Causeway 7 repair yielded a large $(n=463)$ collection of entirely Early Classic sherds (Chacsik and Sabucan phases). The upper three meters of Causeway 2 lacked the usual caprock, but

${ }^{14}$ Returning homeward across southern Campeche in the summer of 1984, Ball stopped at Becán for a short visit and by chance encountered arqueólogo Bueno Cano, who was directing extensive new excavations and stabilization activities at the site that year. Bueno Cano did not initially know who Ball was, but after Ball introduced himself, Bueno Cano lauded the utility of the Becán ceramic sequence, but then proceeded to advance his opinion regarding how completely wrong Webster's and Ball's dating and functional interpretation of the ditch and parapet were. He argued this to be so because they were based solely, according to him, on the presence and condition of the buried Structure XXVII. Bueno Cano asserted that he and colleagues had encountered many cases in their excavations across Mexico in which Early Classic and Late Preclassic platforms had remained in use throughout the length of the Classic period, ultimately being buried beneath later Terminal Classic or Postclassic constructions while still in pristine condition. Pressed by Ball on this, however, Bueno Cano was unable to provide any specific examples. Although he had not conducted (then or later) any probes of the Becán earthwork himself, Bueno Cano further asserted that the abundance of Xcocom complex (Terminal Classic) sherds across the site and of massive Xcocom constructions such as Structures I and IX (or, at least parts of these) "proved" that the giant earthwork had to have been associated with this monumental activity and so of Terminal Classic date. He offered no further support for this opinion, which he later repeated along with the assertion that the ditch was an immense reservoir in an Instituto Nacional de Antropología e Historia de Mexico Colección Científica volume synthesizing the archaeology and cultural history of Becán and the Río Bec architectural region (Bueno Cano 1999:36). instead consisted of fill contained by two retaining walls. Eighty-seven percent of the identifiable sherds from the fill were also Early Classic (late Chacsik) with a small admixture of earlier Pakluum material. Not a single Late Classic or later sherd was recovered from either causeway fill, so they both seem to have been repaired or modified before that time. Either Causeway 2 was originally intended to have this form and was an Early Classic construction, or more plausibly, a Late Preclassic causeway was cut and repaired during the Early Classic. Webster (1976:43) suggested that such causeway alterations were reactions to an Early Classic threat or attack.

We made several long cuts through the embankment, but most deposits were sterile. Only some 171 sherds were found sealed in the undisturbed fill or in the old topsoil beneath it. Of these, 170 were of Pakluum date and the other was Chacsik (Webster 1976: 86). It was primarily this Chacsik sherd that caused Webster to entertain the possibility of Early Classic construction. Ball (Ball and Andrews 1978:14), however, later noted that several Chacsik types emerged during Pakluum times, and so this sherd could well be contemporary with the others. ${ }^{15}$

In her general survey of Maya fortifications, Cortes (2007:140) claims that the Becán earthwork must be Early Classic, primarily because she misreads the stratigraphy of Webster's embankment Trench 21 (Webster 1976:36-37). She says that because the 19 sherds "from the retaining wall" he exposed along the inner side of the embankment were entirely Chacsik, the embankment must be of similar date. ${ }^{16}$ These sherds actually came from a rubble layer above a floor that was clearly later than both the wall and the embankment, and the wall itself might long postdate the original earthwork construction. There were no sherds from the retaining wall, which is simply rough stone, or from the intact sascab fill behind it. In any case, as just noted, several Chacsik types have

\footnotetext{
15 The sherd in question is of the type Xoclan Trickle-on-variegated red (Bartres [ceramic group]) which first appears in terminal facet Pakluum and thereafter continues into Chacsik (Ball 1976:130, 1977a:53, 138).

${ }^{16}$ Note that her Chacsik claim conflicts with the Terminal Classic date asserted by her Mexican colleagues.
} 


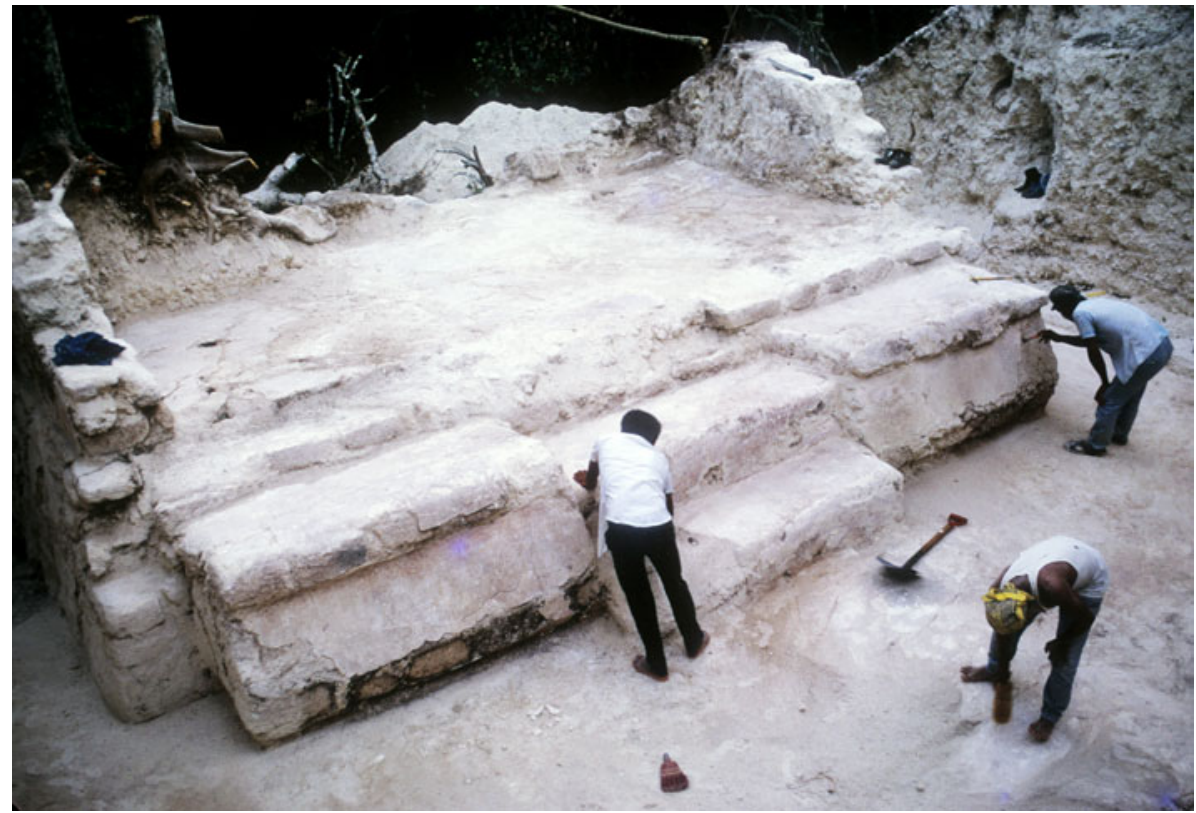

Figure 7. Structure XXVII and adjacent Preclassic floor. Photograph by the authors.

their origins in Late Preclassic times. The unfortunate scarcity of sherds in the embankment fill was disappointing, but also revealing in a negative sense. If a Terminal Classic ditch had been cut through ground already used by the Becán community for centuries, one would expect all sorts of earlier ceramic, architectural, and other debris to wind up in the embankment fill, but this is not the case anywhere we tested.

We recovered large sherd samples from trash thrown into the ditch, especially near the causeways, and also from some intact middens. Most sherds were mixed with sascab washed down from the embankment, and four of the causeways had been widened by purposeful infilling, probably using material from the adjacent embankment. Although most of these contexts are not sealed, the refuse patterns are clear. Ball found that some 86 percent of all the sherd material from the ditch $(n=11,465)$ dates to Late Classic Bejuco times, with earlier Pakluum, Chacsik, and Sabucan sherds mixed in as minority components. Apparently, the fortifications were kept clean and in good repair until about A.D. 600 , and minor local modifications were probably made as well. After maintenance ceased, the sascab fill of the embankment eroded and the trash accumulated, ultimately burying the original ditch floor to a depth of several meters.

Two other points about the relationship between the earthwork and Becán's architecture bear noting. First, with the exception of

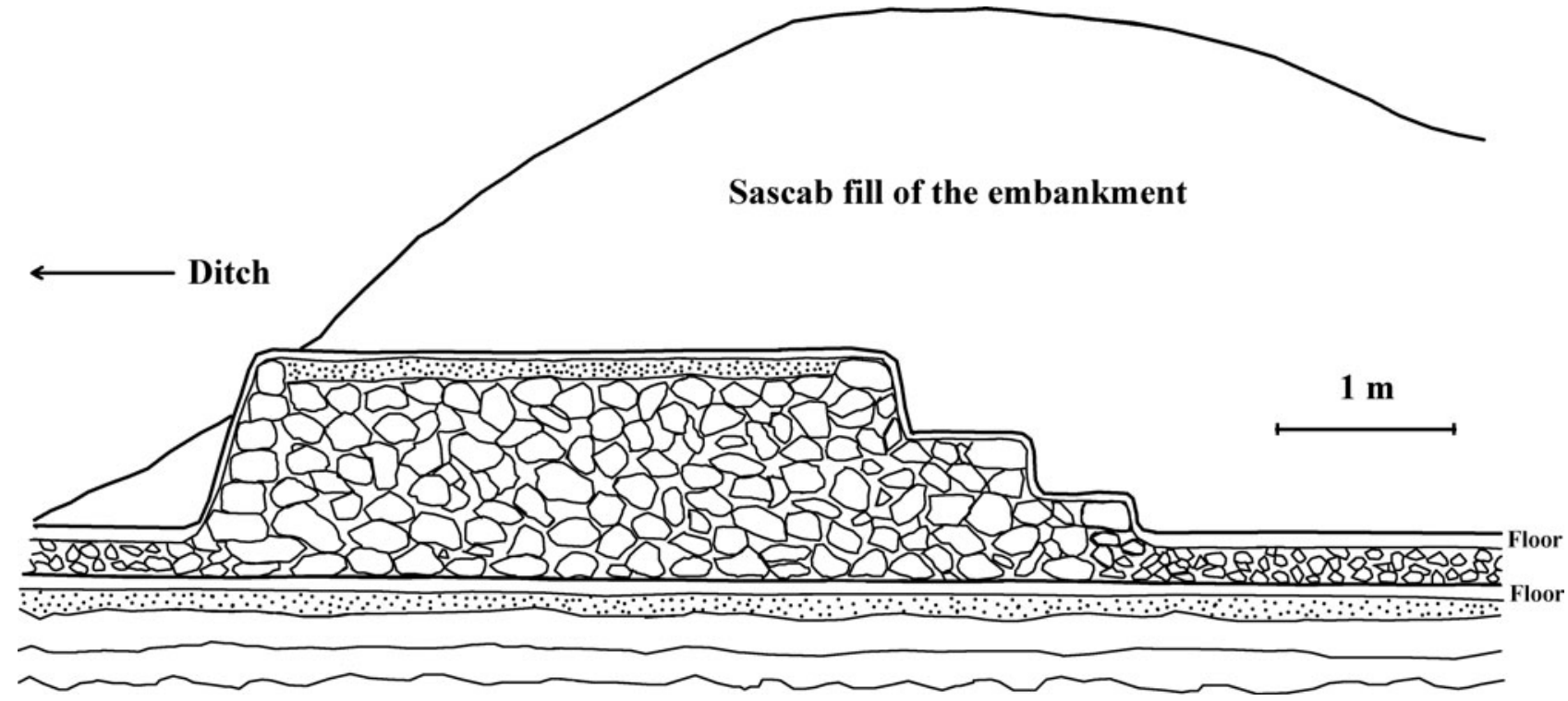

Figure 8. Schematic section through the center of Structure XXVII showing its position below the fill of the embankment and two floors. Image by the authors. 


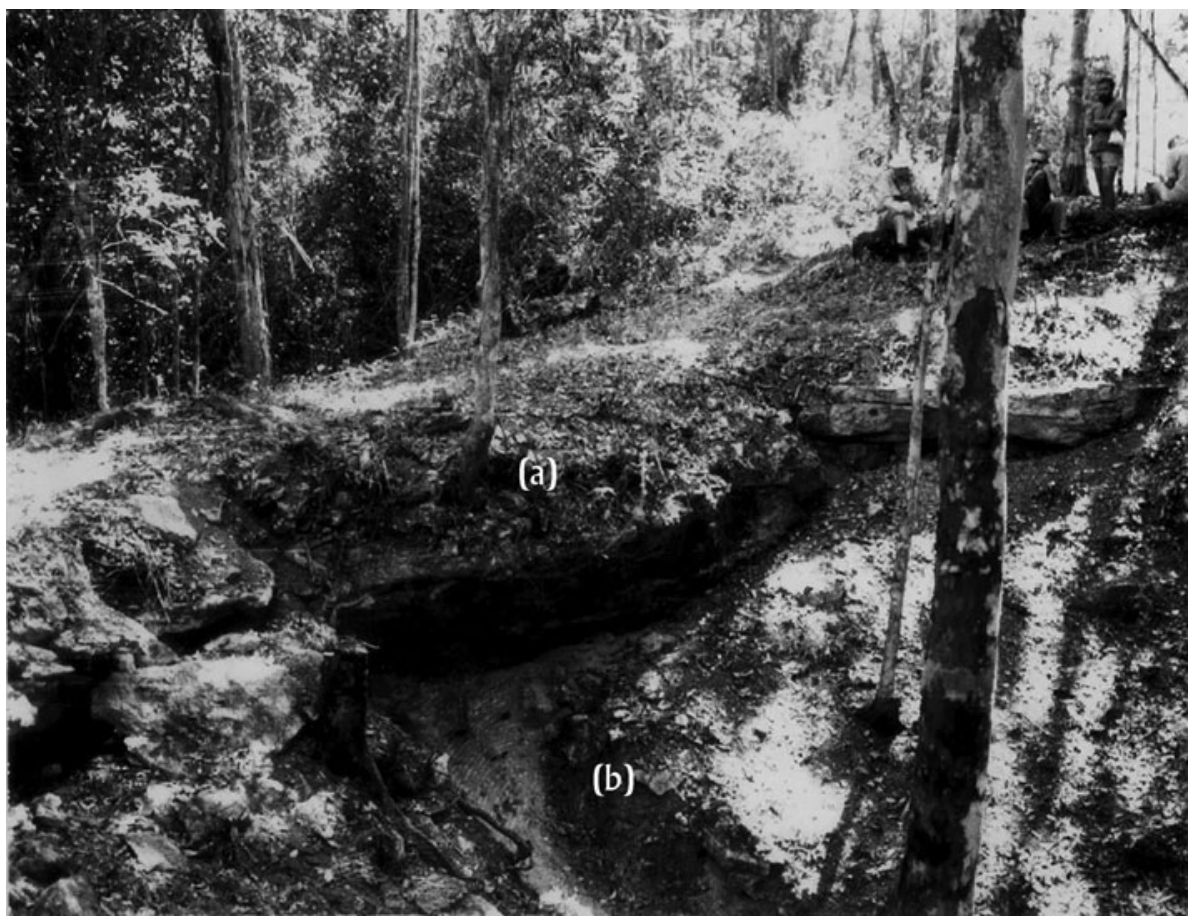

Figure 9. The side of a natural limestone causeway sloping down from the inner edge of the ditch (right). (a) The hard caprock is being undermined by (b) erosion of the underlying softer sascab. Photograph by the authors.

Structure XXVII, we found no indications that the earthwork buried, destroyed, or overrode earlier structures. Webster (1978) later encountered just such contexts at the northern walled center of Cuca in Yucatan. Such superposition is what we would expect at Becán if the earthwork were a Late or Terminal Classic addition to an already well-established and thriving community, as were the little walls at Dos Pilas where such stratigraphy is common (see illustrations in Houston [1993]). ${ }^{17}$ Second, except on the northwest, there are no large structures close to the earthwork along its inside perimeter, and only two within $100 \mathrm{~m}$ outside it. Apparently, the architecture was adjusted to the earthwork, rather than the earthwork to the architecture, and in any case adjacent buildings outside the ditch seem to long postdate construction of the defenses.

All these (and many other) things considered, we reiterate that the embankment, and by inference the earthwork as a whole, dates to sometime between A.D. 100 and 200 and was actively maintained until around A.D. 600. It was a source of building material after that time and was situationally altered to accommodate buildings or to widen causeways. Nevertheless, considerable defensive potential remained long after maintenance ceased. Anyone clambering around the earthwork today in its current state of disrepair will still encounter one of the most formidable defensive barriers in the central and southern Maya lowlands (Figure 10).

\section{WHAT WAS THE FUNCTION OF THE EARTHWORK?}

This is a tricky question because it ascribes a dubious single intention to the Maya builders, and because Ruppert and

\footnotetext{
${ }^{17}$ During later surveys of the Tikal ditch and embankment, we looked for just such superposition, but found none-itself a strong indicator of an early date for the fortifications there as well.
}

Denison obfuscated the issue by naming the site Becán. And here it is important to remember the 36-year interval between the initial recording of the earthwork and our 1970 season. The speculations of Thompson, Pollock, Armillas, and others have since proved remarkably durable, however inconsistent they were with each other and with our 1970 findings. Over the years the earthwork has been variously interpreted as a dry ditch and embankment fortification, a water-filled defensive moat, a feature that collected water for domestic purposes, a flood control barrier, an emic demarcation of social space, a vast borrow pit, or some combination of these.

Two of these suggestions are easily dealt with. It goes without saying that the earthwork defined social space (as most fortifications anywhere do) within the limits of the rocky outcrop or low ridge upon which Becán is perched. Late and Terminal Classic residential constructions inside the earthwork are more substantial than those found on the nearby wider landscape (Thomas 1981) and they probably housed a small population of privileged people and their household retinues. Our informed guess is that the permanent intramural inhabitants of Terminal Classic Becán numbered between 500 and 1,000 people. For them, the old earthworks remained a distinct, if somewhat derelict, social boundary, one that certainly over time might have acquired some kind of ritual landscape significance.

Although the Maya eventually built some large groups outside the ditch (see maps in Campaña [2005] and Thomas [1981]) all the really impressive structures are within it. As we shall see shortly, the ditch and embankment were certainly borrow-pits, but not in the way that Pollock imagined. By far the most stubbornlyheld hypothesis, in the face of clear evidence to the contrary, claims that the manipulation, control, and use of water was the main function of the earthworks (see especially Benevides 2005; Bueno Cano 1999; Campaña 2014). 

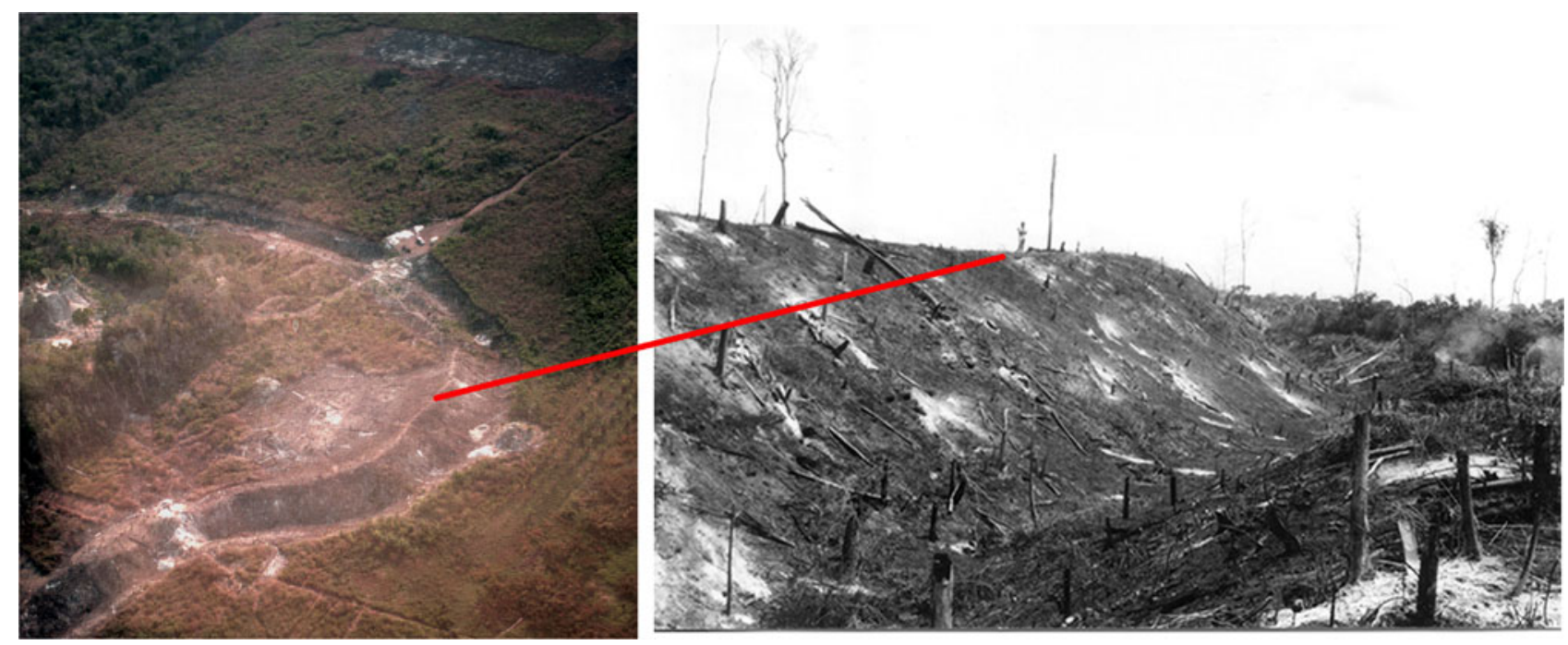

Figure 10. The relict earthwork as an obstacle in 1970. Photographs by the authors.

\section{Water Management or Reservoir?}

In 2005 the archaeologist Benevides (2005:16) recycled the old idea that "Becán is particularly important for being surrounded by a ditch that gathered rain water and facilitated its use," although he grudgingly admitted that the reservoir might also have come in handy during "war times." Bueno Cano had earlier advanced this opinion in his 1999 overview and synthesis of Becán's archaeology, asserting that the ditch and parapet constituted no more than "un almacén para agua," or reservoir (Bueno Cano 1999:36). Campaña Valenzuela (Campaña 2005:49-50), who oversaw major consolidation and restoration at the site between 1999 and 2004, similarly proffered a number of unsupported assertions that the great ditch and parapet amounted to nothing more than an elaborate drainage system and giant borrow pit bordering commoner residential platforms, all possibly dating no earlier than the beginning of the Terminal Classic period (Bueno Cano 1999).

These opinions were both puzzling and groundless, and recently Campaña (2014:141) doubled down, insisting again that the ditch was no more than a giant water-control drainage system and with no new supporting evidence other than expedient logic:

Sin embargo, el análisis fisiográfico a partir del levantamiento topográphico y las ausencia de canteras [quarries] en las inmediaciones del sitio sugieron motivaciones prácticas para la ejecución de esta obra mayor [aparte de la defensa] como son la conducción y drenaje del agua superficial y el abastecimiento de piedra para la construcción de edificios.

Let us be very clear about this water business. Despite its unfortunate name, the ditch was not formed by water, it is not a barranca in any sense of the word, it was not a water reservoir, nor was it any other kind of intentional water feature. ${ }^{18}$ A short anecdote shows how the water management hypothesis has nevertheless long exercised a tenacious grip on some archaeological imaginations. In the mid-1990s Arqueologia Mexicana solicited an article on Becán

${ }^{18}$ Some other early defenses do combine earthworks with water barriers, as at Tintal, Edzna, Cerros, and possibly Punta de Chimino and Nixtun-Ch'ich'. from Webster (Webster 1996). The editors requested reconstruction drawings of the earthwork, which he duly provided. When the article appeared in 1996, the composite illustration made from Webster's drawings of a dry ditch was curiously transmuted into a water-filled moat (Figure 11), despite the fact that he has always denied such an explanation and did not make this claim in the text of the article, in his submitted drawings, or anywhere else. ${ }^{19}$

Becán is located in relatively well-watered country, both in terms of rainfall and surface sources. Annual precipitation at the time of our work averaged around 1,500 $\mathrm{mm}$ (Vogeler 1974) and in this part of Campeche generally ranges between 1,000-2,000 mm, with comparatively low yearly variation. Thomas (1981:96) noted that the attractions of the locale for early settlers included the "well-drained terrain and abundant water of the nearby natural aguadas." Large seasonal bajos border the site on the northeast and south and were natural deterrents to wet season attacks. These bajos are now much silted in, and they must have had more standing dry season water during earlier times. There is a small aguada within the fortifications, but the main water source when we worked there was Aguada Carmelita, about 500 meters south of the ruins and connected to them by a causeway (Figure 12). The aguada, at least partly artificial, is a rough square about 125 meters on a side and was clearly the main water source for Becan's inhabitants (Nicholas Dunning, personal communication 2021). Nevertheless, like most of the central and southern lowlands, the Becán region is prone to serious and unpredictable short droughts. Thomas (1981:2) described the effects of droughts in 1972 and 1975 on the communities of newly-established migrant farmers around Becán. These people would probably have been forced to abandon their homes and relocate had trucks not delivered water from distant sources (we got most of the water for our camp the same way). That there were similar shortages in earlier times seems likely given new reconstructions of climatic history (see section Climate Change).

\footnotetext{
${ }^{19}$ They also unilaterally titled the article "Una ciudad maya fortificada: Becán, Campeche," despite the fact that Webster (1996) would never label Becán a "city."
} 

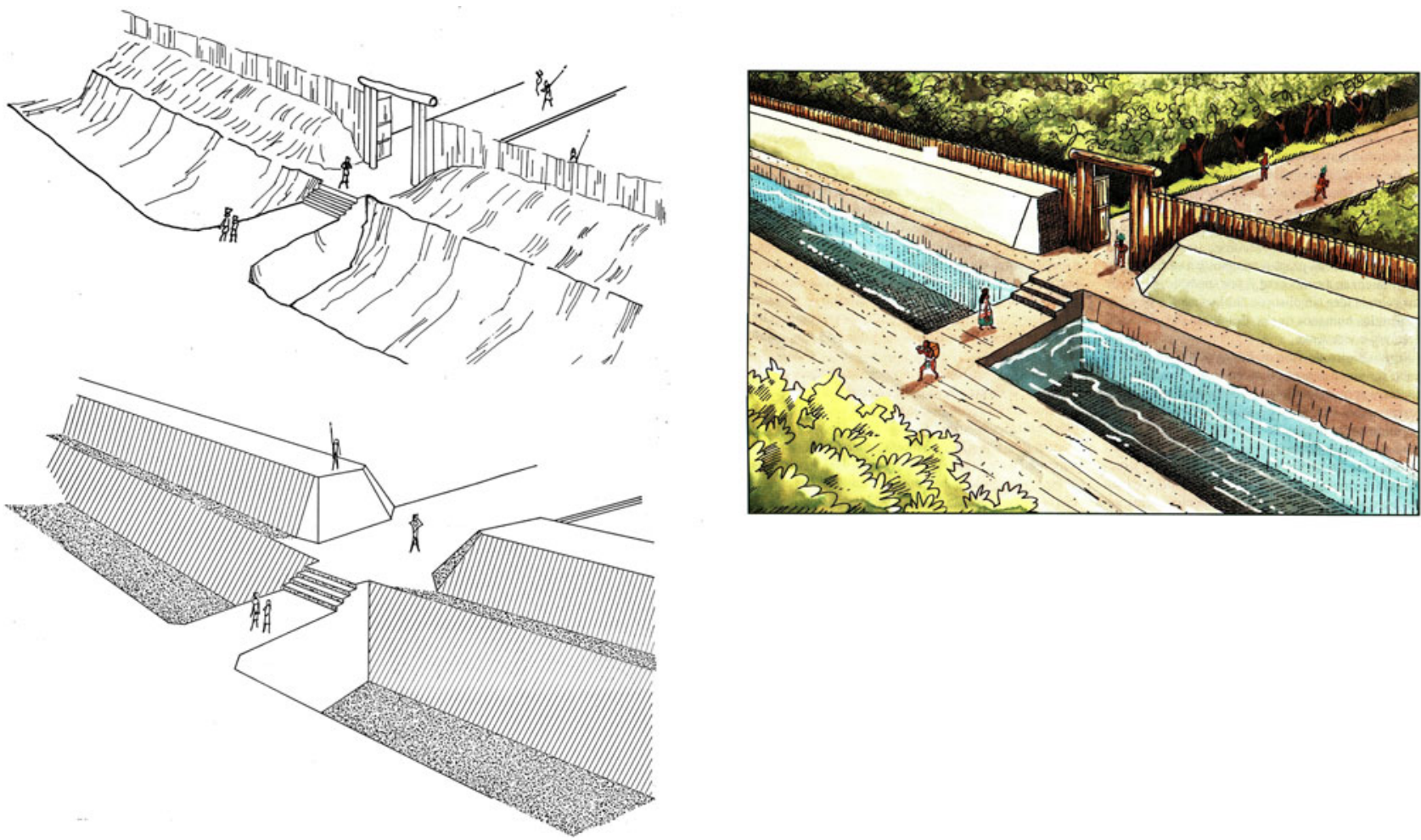

Figure 11. Webster's submitted images (left) and the mysteriously transformed published version.

The two main arguments against the water management explanation focus on engineering design and sedimentation. Thompson carefully read Ruppert's and Denison's description of the ditch, which said that its bottom in one section was some 16 feet higher than the adjacent swamp-the water source for a true moat. He also saw what appeared to be an inlet channel on the outer side of the ditch between Causeways 5 and 6 . Because Thompson believed the moat was engineered to be flooded, he concluded that it was never completed because water could not have flowed around the whole ditch. Webster's later contour-mapping showed that Rupert's and Denison's calculations were correct. Although the ditch maintains its general cross-section around the perimeter of the site, its bottom on the northwest is seven to $10 \mathrm{~m}$ higher than on the southeast. Had water seeped into the ditch from the bajos

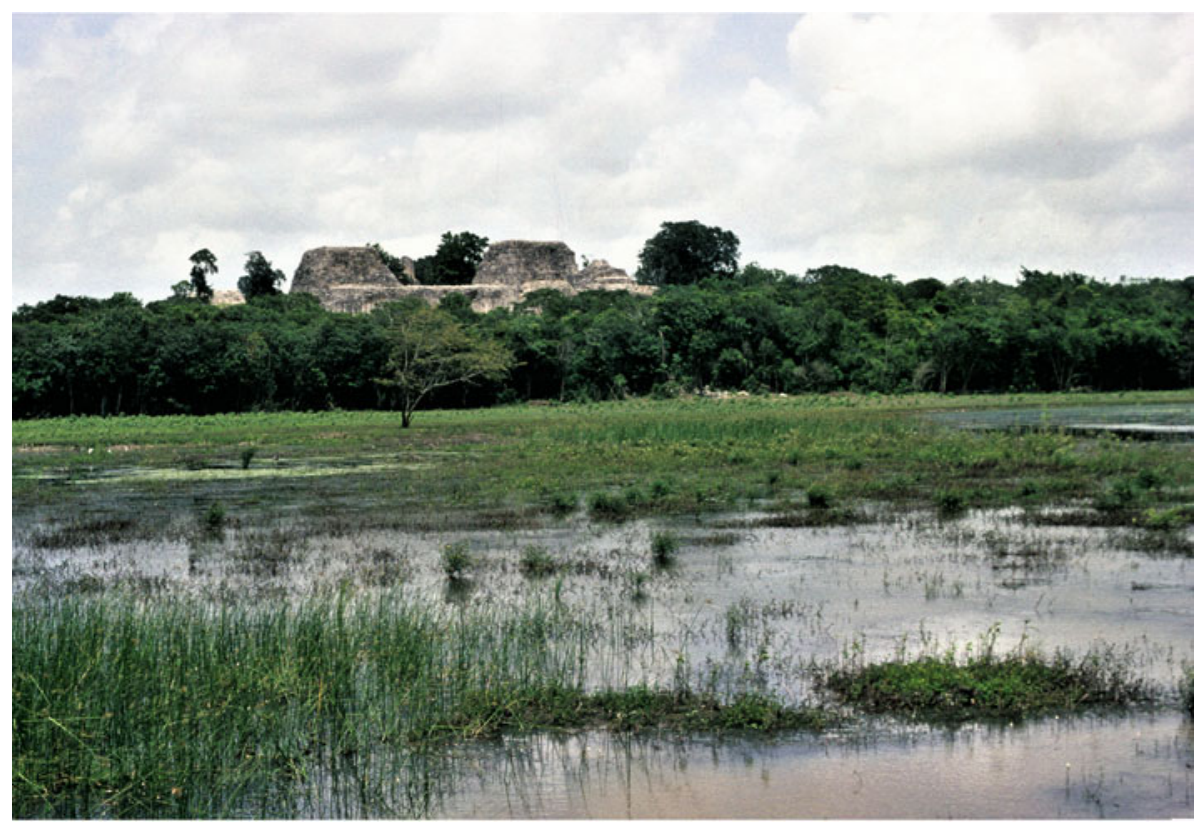

Figure 12. Flooded bajo to the south of Becán. Photograph by the authors. 
to the northeast it would simply have puddled-up in the sections there. Another telling point is that during wet intervals the water in Aguada Carmelita is perched at a higher level than the original ditch bottom. Nevertheless, there are no sediments indicating any overflow or seepage onto the original floor of the adjacent southern ditch.

Two other obvious engineering objections were anticipated by Armillas. The causeways are simply solid rock left in place when the ditch segments were dug. They were never pierced to allow the flow of water because this was not the intention of the Maya, not because the moat system was unfinished. Armillas also correctly stressed the porousness of the sascab. Had the causeways been pierced to channel water, their sascab foundations would have dissolved, causing them to collapse.

As far as we know, Webster and his workmen are the only people who have recently stood on the original bottom of the ditch and examined its deposits (Figure 13). Any hole in the ground, dug for whatever purpose, in a tropical region that gets 1,000-2,000 $\mathrm{mm}$ of rain annually, admittedly accumulates water. That said, we encountered sediments indicative of significant water input and retention (e.g., dark clays and organic materials) only in the two northeastern segments of the ditch that are closely flanked by bajos. This part of the ditch, however, is still perfectly clear to anyone walking along it, as is the embankment. Although some water-deposited sediments accumulated in it, it was never silted up enough to obscure the outer or inner lips of the ditch-the presumed maximal level of the bajos. Had there been danger from flooding in this zone, the hydrological solution would have been to allow the water to drain off to the east and south, but solid causeway construction prevented such flow. The sediments we observed might, moreover, have been deposited long after the earthwork fell into disuse and the bajos had silted in. Even then, however, this northeastern segment of Becán's perimeter was never vulnerable to significant flooding, and we know of no flood deposits found anywhere inside the perimeter of the embankment. Neither, as far as we know, has anyone found drainage features like those at Tikal that funnel runoff from the interior architecture into the ditch segments to supply reservoirs. In short, there was never a water-filled barrier like those common in medieval Europe, although the ditch is often represented in that way despite our repeated protests. Whatever its incidental hydrological or other functions, the earthwork was intended as a dry ditch and embankment fortification pure and simple, despite the data-free assertions of Benevides, Bueno Cano, Campaña, and others.

Finally, imagine for the moment that the ditch segments were purposely constructed reservoirs or flood control barriers. One could make the argument that drought and flood vulnerability support our Late Preclassic date. If flooding were a serious problem, why wait until Late or Terminal Classic times to control it? If, on the other hand, the purported ditch/reservoir was built that recently, how did earlier populations cope with water shortages or floods? We shall see shortly that there was a major regional dry spell during the Late Preclassic that would probably have lowered water levels in the bajos.

\section{Borrow Pit?}

None of the foregoing tells us much about Becán's Late Preclassic settlement or construction efforts, which are central to the borrowpit hypothesis. There are some impressive Late Preclassic buildings, most notably Structure IX-sub and Structure E-IV-sub. More generally, "Pakluum structures, floors, and rubbish are distributed densely and consistently within the fortified zone and across the surrounding countryside" (Ball and Andrews 1978:15). Later intensive reworking of the site destroyed or buried many insubstantial early buildings. An example is Structure XXII, a low (2.5 m) but extensive platform on a slight rise in the bedrock (Figure 10). Webster tested it with several large trenches and uncovered many fragmentary floors and walls. The locale was used well into Late Classic times, but his probes produced a high frequency (about 40 percent) of Late Preclassic sherds, probably scraped up locally and used as fill. Preclassic occupation in this vicinity helps explain the odd southern bulge in the earthwork between Causeways 7 and 1 -it accommodated a prime early habitation spot. Most early constructions inside the ditch were generally modest but widely distributed, and Becán's Terminal Preclassic population might have compared favorably with its Late Classic one.

Our insistence on the primacy of fortification does not preclude other uses, and in this Campaña is half-right. The ditch was certainly a borrow pit, as Webster said in his dissertation. He calculated the volume of fill dug from the ditch at roughly $117,607 \mathrm{~m}^{3}$, equivalent to more than nine Tikal Temple 1s (Webster and Kirker 1995). This represents a mass probably greater than all the other structures ever built at Becán combined. ${ }^{20}$ Of this amount, about one-third (the volumetric equivalent of three Temple 1s) was in the form of hard limestone caprock. Because the Maya removed this material first, we expected to find it redeposited, along with old topsoil, to form the basal layers of the embankment. Instead the embankment fill, as shown above, consisted almost entirely of loose sascab with dark soil lenses at its base, so the Maya clearly hauled off the caprock to use elsewhere. We also saw that there are low sections of the parapet where the sascab fill was removed or leveled off, as beneath Structure XXV. Where did all this material go, and when did such reconfigurations take place?

Our conventional Becán map shown in Figure 1 is a kind of reverse palimpsest of early and late features, and it takes real mental effort to disentangle the visible surface architecture, which is Late Classic or later, from the much earlier earthworks. ${ }^{21}$ In Figure 14 we eliminate it and show where there were some Late Preclassic buildings. Not depicted here are the "essentially unbroken expanses of sascab-cement plaza floors, terraces, platforms, and pyramidal structures-all of late through terminal facet Pakluum age" that were scattered widely over the intramural zone (Ball and Andrews 1978:15; see also Bueno Cano 1999). Becán's vigorous Late Preclassic settlement expansion required masses of hard fill to level off the outcrop, to build the first big formal plazas and structures, and to produce plaster to surface them. Caprock from the ditch was ideal for these purposes.

\footnotetext{
${ }^{20}$ Some archaeologists might object that the juxtaposition of Becán and Copan shown in Figure 3 is misleading because it does not take into account the mass of Copan's Acropolis. There are, however, very large buildings at Becán, and if the earthwork is taken into account, construction effort there was greater than at Copan in terms of sheer mass. Imagine adding the mass equivalent of nine Temple 1 buildings to the Copan Main Group.

${ }^{21}$ In a true palimpsest faint traces of earlier information layers show through the final superimposed one. Becán's earthwork is by far the largest built feature, so early information visually dominates the later architectural additions, hence reversing the palimpsest principle.
} 

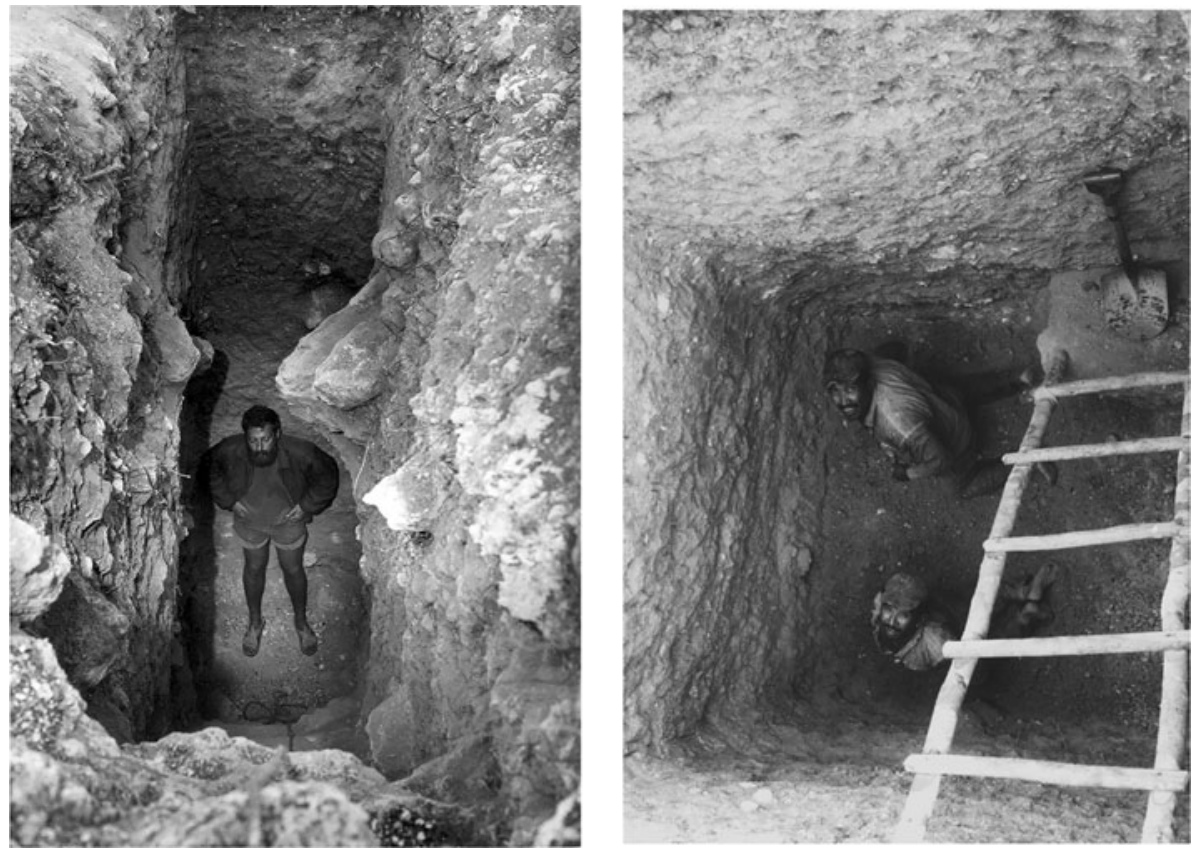

Figure 13. Webster, Ignacio, and Gilberto on the floors of two deep ditch soundings. Photographs by the authors.

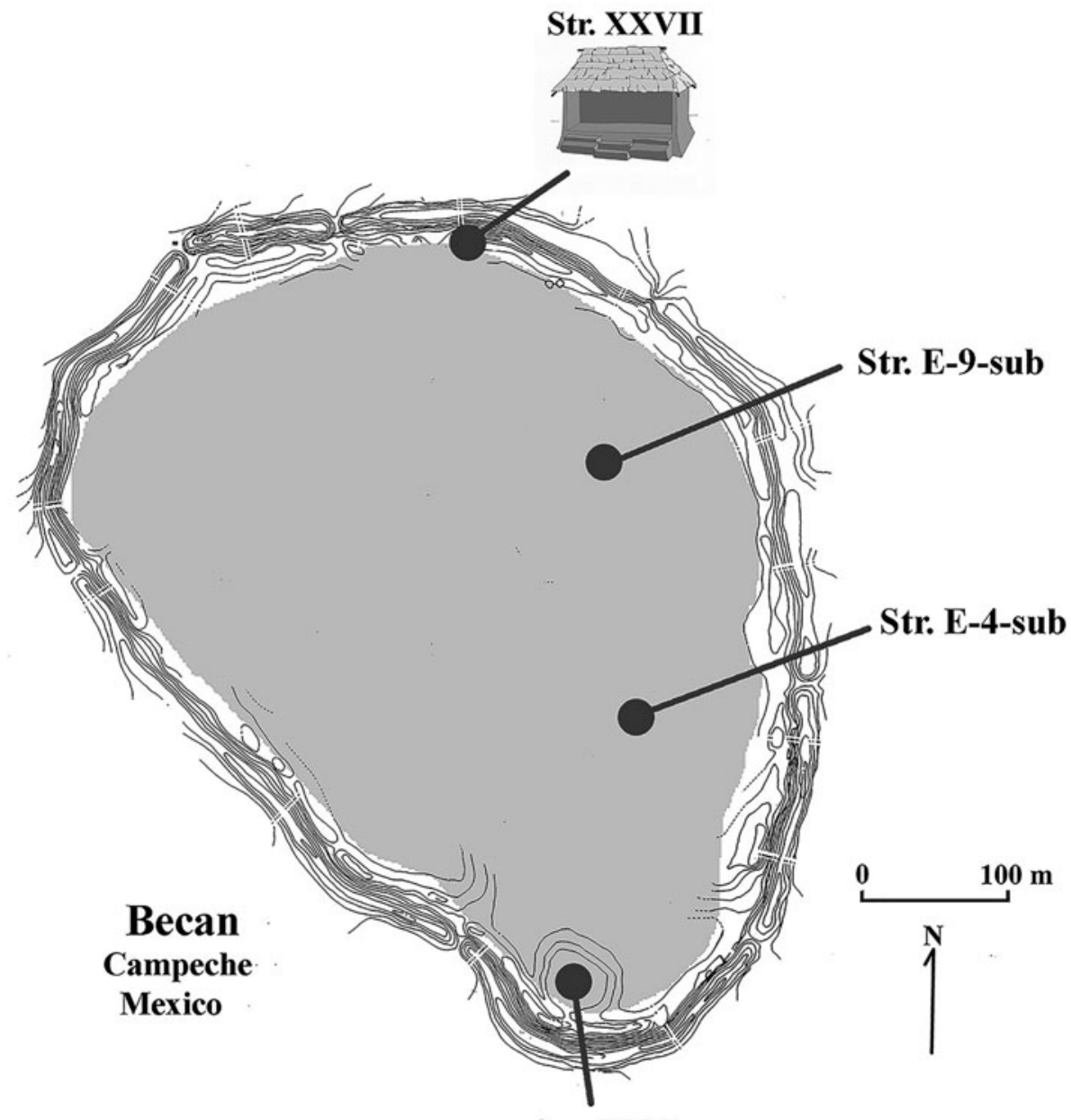

Str. XXII

Figure 14. Locations of Pakluum construction; Pakluum debris encountered widely in the shaded area. Image by the authors. 


\section{PRE-PAKLUUM BECÁN}

Based on the extent and monumentality of Pakluum-dated construction across the site, in his dissertation Ball (1973) envisioned Late Preclassic Becán as the "sociopolitical or ceremonial heart of the region" and fixed Becan's initial occupation early in the Late Preclassic. We now know that lurking behind the abundant Pakluum constructions, ceramics, and household remains is an even deeper occupation than he suspected. Not until Ball's 1977 MARI monograph did he identify and add the Mamom horizon Acachen complex, based on discoveries made during the 1973 University of Wisconsin excavations. The Wisconsin archaeologists detected a very scant, but nonetheless pure, full Middle Preclassic Mamom ceramic presence within the confines of the earthwork. When Prentice Thomas tested a large plazuela group about 400 meters south-southeast of the great ditch, he recovered a foundation cache consisting of nine broken, but whole, ceramic vessels and a large chert biface. This feature was never adequately presented, described, or published, and without contemporary points of reference at the time, Thomas simply shoehorned the vessels into established Acachen-Mamom types in his unpublished 1983 field report and assigned a date of post-550 B.C. to them.

Ball later examined and photographed the vessels (Figure 15) in the Instituto Nacional de Antropología e Historia collections in Merida with the permission of Director Norberto Gonzalez Crespo, and he recognized them as troublesomely aberrant. Since then, based on publication of numerous early finds from throughout the Maya lowlands, he has come to recognize these vessels as belonging to types and varieties established at Cuello, Belize, by Kosakowsky (1987; Kosakowsky et al. 2018). They belong to the pre-Mamom Bladen ceramic complex, dated to ca. 800-550 B.C. Šprajc's 2013-2018 Slovenian archaeological reconnaissance project north of Becán (Figure 16) also recovered both Mamom-equivalent and earlier Middle Preclassic sherds from multiple places throughout their survey zone, including beneath the Classic period centers of Lagunita, Tamchen, and Chactun (Ball 2015, 2017, 2021; Dzul Gongora 2020; Šprajc 2021). Despite the small sample of pre-Acachen complex sherds from Becán, it seems certain that there was already a well-established community there by the early to mid- to first millennium B.C., with its later Pakluum florescence, including the earthwork, signaling its leap to regional prominence.

Becán's Middle Preclassic settlers were probably too few to muster the labor necessary for big constructions. Although the size of the region's later Pakluum population is unknown, such a labor force was clearly available by that time. ${ }^{22}$ Unlike accretional Maya buildings such as those in Tikal's North Acropolis or in Copan's Acropolis, the Becán earthwork was built as a single effort over a comparatively short time, with only a few later modifications. Social and political costs were correspondingly large, but energetic investment was low, requiring mainly unskilled

${ }^{22}$ Thomas's thorough but restricted $\left(3 \mathrm{~km}^{2}\right)$ settlement survey around Becán did produce some numbers. He estimated a maximal Late Preclassic population of 1,316 people for this zone, and a density of 479 people per $\mathrm{km}^{2}$ (Thomas 1981:109-112). Calculated this way, the Late Preclassic population was larger and denser than at any later time period, and there was a bimodal demographic profile for Becán's occupational history. Density implications were still unclear because of uncertainty about how the Pakluum population fits its 550-year duration. When he adjusted his estimates by ceramic phase duration, a more normal curve resulted with a proportionately much reduced Pakluum population. How far Becán's political hinterland extended at A.D. 100-250 is unknown.

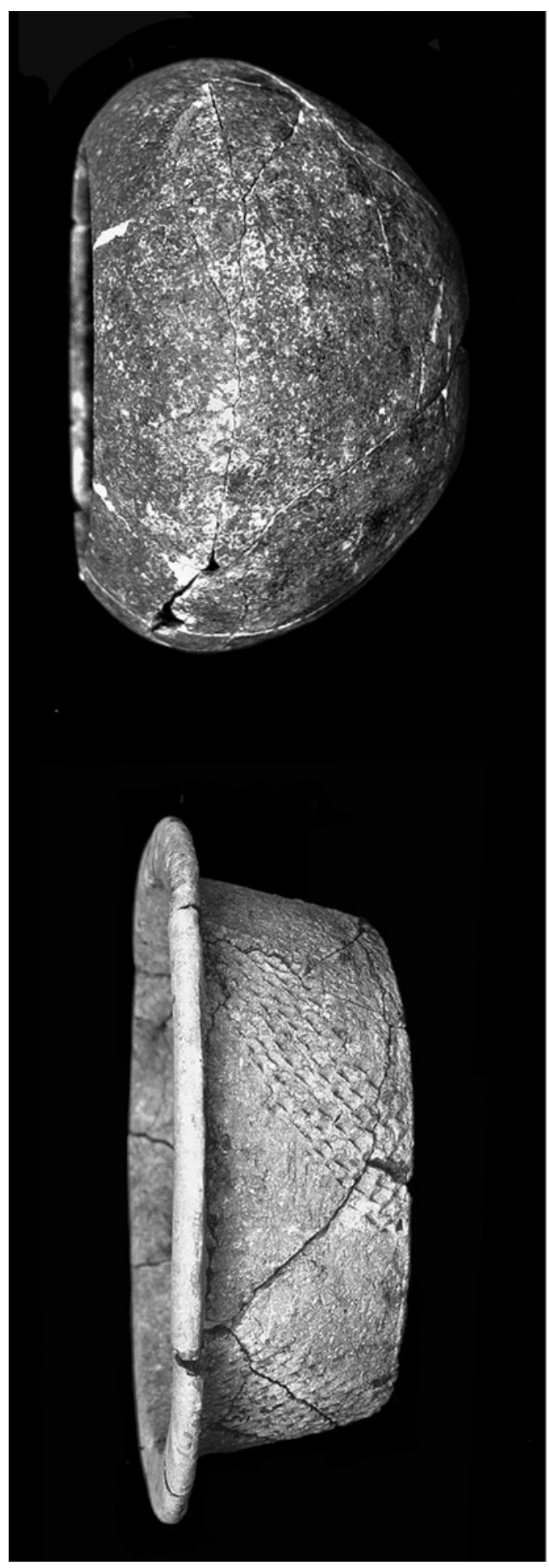

Figure 15. Pre-Mamom vessels from the cache found by Thomas in 1973. Photograph by the authors.

excavation and minimal transport. A full-time work force of 1,000 people could have built the earthworks in a year or so, or somewhat more if there were a timber palisade or some sort of screen or hedge of thorny vegetation atop the embankment (Webster 1976:97).

Archaeologists who deal with Maya infrastructure sometimes make the distinction between "sunk cost" and "capital" investments. 


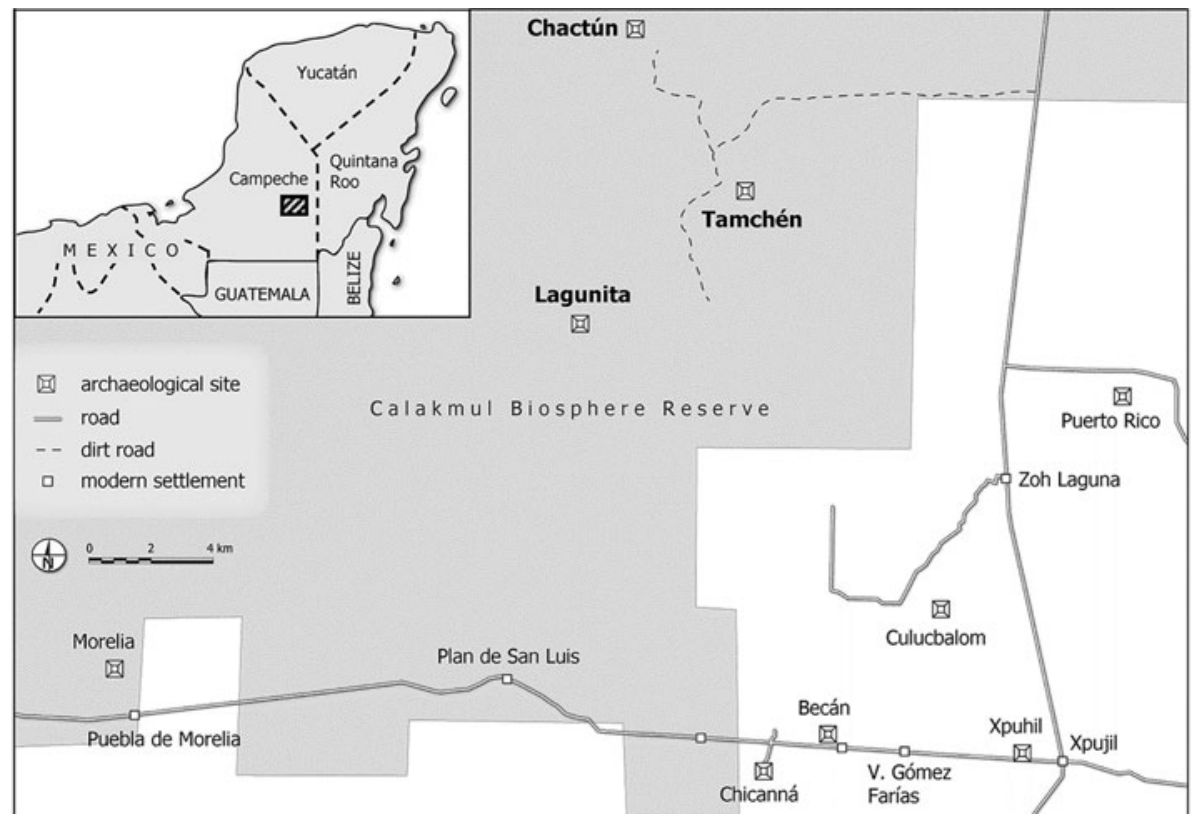

Figure 16. Map of the region to the northwest of Becán showing the locations of Chactún and the smaller centers of Tamchén and Lagunita. Image from Šprajc (2021) and used with his permission.

The former include tombs, palaces, and temples, and other constructions that, however imposing, produce no immediate and tangible economic returns. Capital constructions such as dams, irrigation canals, terraces, or drained field systems, by contrast, have just such payoffs. ${ }^{23}$ Other features do not fall neatly into either of these categories. Fortifications like Becán's are an obvious example, in the sense that their payoff is not economic gain, but the immediate existential survival of a community. ${ }^{24}$ While earthwork construction at Becán was monumental, it could not have been gradual and incremental in the face of some perceived threat.

Elsewhere we have commented on Becán's implications for large-scale warfare and associated offensive and defensive strategies and tactics. It bears emphasizing, however, that there was no dense mass of households clustered around the earthwork comparable to those surrounding the central precincts of Tikal or Copan. ${ }^{25}$ At both these centers large concentrations of people probably formed effective defensive screens, especially against surprise attacks, but this was not the case at Becán.

\section{BECAN'S CULTURAL HISTORY IN THE CENTRAL AND SOUTHERN LOWLANDS}

Webster knows from experience at five fortified centers what many other colleagues such as Scherer and Golden (2018) have also

${ }^{23}$ The huge investments made by the Mexica-Tenocha state in dykes, dams, aqueducts, and causeways in the southern lakes of the Basin of Mexico are among the most impressive construction efforts in pre-Columbian Mesoamerica, and dwarf its civic monuments in terms of mass.

${ }^{24}$ Some fortifications are created to project offensive power, and these obviously might have direct economic consequences. And of course almost all monumental constructions might be said to have symbolic meaning and to stimulate social integration, and so create social capital.

${ }^{25}$ In his review of the Becán settlement, Thomas (1981) noted that the defenses never stimulated a marked contraction of population outside the defensive perimeter, whatever the various threats to the local community might have been. discovered: Maya defensive features, and particularly earthworks and walls, are notoriously difficult to date directly. ${ }^{26}$ When there is chronological ambiguity or disagreement, the temptation is to identify background intervals of crisis or instability and assign the defensive features to whichever one prefers. This is what Thompson and Pollock did for Becán, and what Puleston and Callender later did for the Tikal earthworks. In the same vein, Guenter (2002:176) reasoned that "Tikal's earthworks date to around 650 and were constructed either at the end of the reign of K'inich Muwaahn Jol II or at the beginning of the reign of Nu'n u Jol Chaahk, when Tikal had lost Uaxactún to the forces of the Snake lords to the north." 27 Still more recently, Garrison and Houston (2018a, 2018b) suggest that the Tikal earthworks might be earlier than Puleston and Guenter surmised-either fourth or fifth century. Their interpretation is based on fortifications turned up by lidar just to the west of Tikal, and by reinterpretation of the Tikal system (Webster et al. 2004, 2007). Garrison and Houston hypothesize that their newly detected La Cuernavilla system of fortifications near the center of El Zotz relates either to Tikal's early westward expansion just after the celebrated A.D. 378 event (Stuart 2000), or to possible conflict between Tikal and the El

${ }^{26}$ During our recent Penn State projects at Tikal, we placed 32 trenches, some very large, in and around the earthwork. We never found any definitive evidence for its construction date and very few artifacts.

${ }^{27}$ Guenter (2002:175-176) called Tikal's northern earthwork the single greatest construction project at the site. Haviland (2003:136) estimated the fill removed at $114,000 \mathrm{~m}^{3}$, just short of Webster's estimate for the whole Becán ditch. Haviland's figure is probably a significant overestimate because he did not understand the variability of the Tikal ditch segments; neither of course did he know about the new segments we later discovered. During our Penn State University Tikal project, Murtha roughly calculated the fill removed from all known sections of the ditch at $260,000 \mathrm{~m}^{3}$, or the mass equivalent of 14 Temple1s. This figure does not include the new western sections that have shown up on lidar since our Pennsylvania State University research (Canuto et al. 2018). Guenter is thus correct in terms of sheer scale if all earthwork segments he knew about are considered, but we have no idea how labor was allocated over time. 
Zotz kingdom in the Buenavista Valley. All such assignments, of course, are hypothetical until backed up by archaeological evidence.

\section{Many Times or Intervals of Trouble}

Consider the many potential times of trouble for Becán, both general and specific, that have been identified by research since 1970:

(1) A major Late Preclassic dry spell from about A.D. 100-300 (Dunning et al. 2014; Ebert et. al 2017).

(2) Disruption of the great El Mirador polities at about A.D. 150-250, characterized by political collapse, new institutions of kingship, and also by population declines or diasporas.

(3) Pulses of general Teotihuacan-related influence in the Maya lowlands between A.D. 200-400. that roughly correlate with Ball's detection of an Early Classic decline at Becán at about A.D. 250-450. ${ }^{28}$

(4) The "arrival of strangers" at Tikal in A.D. 378 and the expansion of a Teotihuacan/Tikal political order.

(5) Archaeological evidence strongly suggestive of an attack on Becán during late Chacsik or initial Sabucan times, between ca. A.D. 400 and $460 / 500$.

(6) The struggles between the Kaanu'l and Tikal hegemonies that began about A.D. 540 and lasted until about A.D. 750.

(7) Disruption related to volcanic events of the mid-sixth century, including the eruption of the Ilopango volcano in El Salvador (or maybe in Iceland). ${ }^{29}$

(8) Ball's (2014) recent detection of an interval of serious decline or outright abandonment at Becán between about A.D. 730/750 and 830, followed by repopulation by people using distinctive, northern-related pottery.

(9) The general turmoil of the southern Maya collapse between about A.D. 750 and $900 .^{30}$

(10) The proposed great regional "megadroughts" between about A.D. 850 and 1100 .

We can regard these episodes separately, but they resolve themselves into complex concatenations of vulnerability as graphed out in subsequent figures. The question is, how do we apportion potential construction, alteration, or extended use of the earthwork among all this potential instability? We surmised in 1970 that Becán might have suffered some sort of Teotihuacan-related threat or actual attack around A.D. 440-460, more or less in line with presumed conflict between Tikal and Uaxactun, and just before what then seemed to be a major Tikal hiatus. All this was too late for our proposed construction date.

The first two options (Figure 17) roughly correlate with what Estrada-Belli (2011:61) identifies as a transformational "conjunction" episode in southern Maya culture history. They fit our construction date for the earthworks almost perfectly and lend credence to it. The

${ }^{28}$ Ball originally thought that Becán's Early Classic Chacsik phase was a time of decline and a distinct fall-off in construction, with outlying population near the earthworks. Thomas (1981:98) instead detected continued expansion of peripheral population, though agreeing that construction was sparse.

${ }^{29}$ The Ilopango eruption was equated by many volcanologists with the famous A.D. 536 event that affected many parts of the world (see Dahlin and Chase [2014] for possible effects on the Maya). New research now suggests that there were several major eruptions during the interval, and that Ilopango probably blew in A.D. 539-540 (Dull et al. 2019), although some would put it earlier, at about A.D. 431 (Smith et al. 2020).

${ }^{30}$ Becán's Late Classic "collapse" around the middle of the eighth century superficially aligns with the larger Classic collapse throughout the central and southern lowlands. Its period of abandonment and upheaval was of short duration, however, and was followed by demographic resurgence and considerable architectural vigor. "arrival of strangers" option, on the other hand, is too late (but see section A Testable Conjecture). We already saw that the earthwork was maintained and cleaned until about A.D. 600. During this extended interval of active use (Figure 18) there were several other local and regional threats (options 3-7).

\section{Case Study: An Early Classic Attack on Becán During the Great Hegemonic Struggles}

The big threat (options 4-6) that might be linked to violence at Becán was the inception of the Tikal/Snake dynasty wars around A.D. 540 (Martin 2020; Martin and Grube 1995, 2008), which suspiciously coincides with estimates for the Ilopango eruption. Archaeological data supporting this attack on Becán has never been published, apart from short comments and a brief summary by Ball (1971:25-26, 1977a:170-171, 1979). Here is what we know.

In 1969 Simmons, Thomas, and Wright did preliminary excavations at Becán in anticipation of our 1970 season (Simmons et al. 1969). Simmons cleared the impressive Structure XIV-sub (see Figure 1), a likely multiroom, Chacsik-phase palace that had been systematically in-filled and buried. Its replacement, the overlying Sabucan phase Structure XIV, was a large platform with probable talud-tablero elements. The superstructure, of unknown function, had been violently and comprehensively demolished. The wellknown Teotihuacan-style terracotta host statuette with its interior complement of 10 Teotihuacan "cookie cutter" figurines was recovered from a cache in the rubble core of the Sabucan platform (Ball 1974, 1979), although its exact stratigraphic context is unclear. The inarguably Teotihuacan-manufactured ensemble was seated within an exceptionally fine, plano-relief carved, brown glossware tripod cylinder vase of southern lowlands origin. Glossware tripod cylinder vases and apron lids fragments are not found at Becán during Chacsik times, but are abundant in the lowermost Sabucan deposits and levels. Then they entirely disappear. Such wares are, of course, hallmarks of Teotihuacan influence during the southern lowland Tzakol 3 horizon of the Early Classic after A.D. 378, and well-known from literally all southern lowland sites. Several authors, including Braswell (in Volta et al. 2020), have remarked in passing that these form(s) do not occur at Calakmul or Dzibanche, at least as far as is known to date from the published literature.

Two separate test pits, probably dug by Thomas and Wright, were situated to the immediate north and northeast of the north end of the Late Classic palace complex, collectively called "Structure XIII." These two pits, whose contents were later analyzed by Ball and Rovner, tapped into an apparent early Sabucan destruction level strewn with human skeletal remains. Five bifacial broken dart or spear points were recovered from deposits of ambiguous Chacsik/Sabucan date from Structure XIV and from the two destruction-level pits. Four of the points were made of green obsidian, and one from a grey variety from an unidentified central Mexican source according to PIXE analysis. The precise dating and significance of these remains are open questions, but clues come from Becan's obsidian and ceramic assemblages.

\section{Political Implications of Becán's Obsidian}

Becán is deep in Snake country, about 70 kilometers northeast of Calakmul (Figure 19). We find it difficult to imagine that it was unaffected by the repeated Kaanu'l wars with Tikal, including those that occurred between A.D. 695 and 744 as Tikal regained 


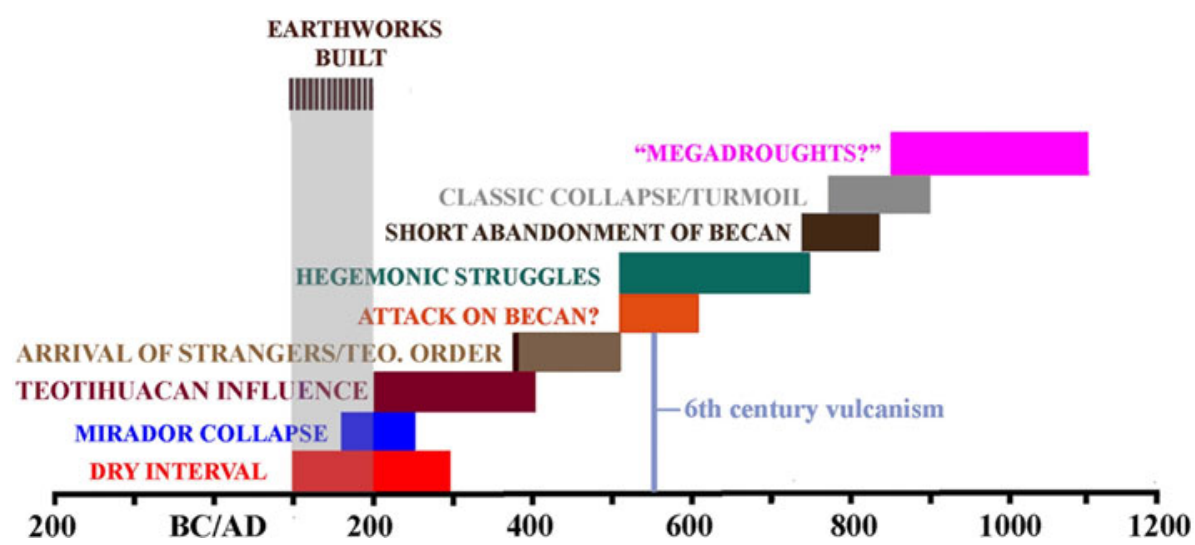

Figure 17. Times or intervals of plausible instability or crisis at Becán juxtaposed with period of construction. Image by the authors.

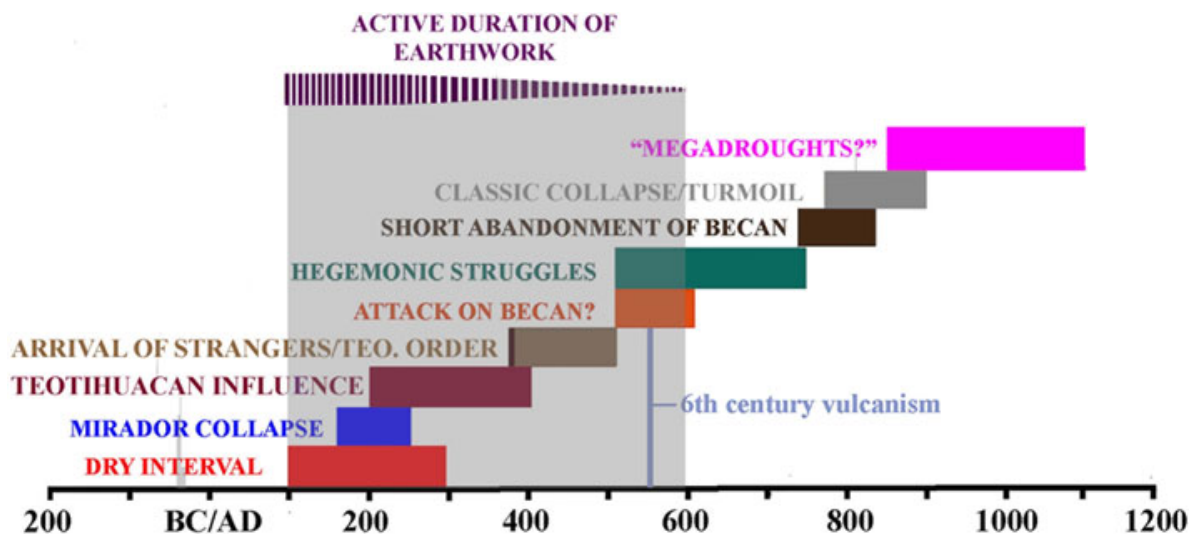

Figure 18. Times or intervals of plausible instability or crisis at Becán juxtaposed with interval of active maintenance of the earthwork. Image by the authors.

dominance. A look at some venerable obsidian data raises some new ideas about this struggle.

A major but generally forgotten contribution to Maya studies made by the Tulane-Wisconsin Becán project was the elaboration of the first true lithic sequence anywhere in the Maya lowlands. It presented a contextually comprehensive study of the obsidian artifacts from the site, and a careful analysis of their chronological as well as their spatial and depositional distributions. The heavy lifting in this endeavor was done by Rovner (1974, 1975), who joined the project in 1971 as part of his doctoral dissertation (Rovner 1975) research on the lithics of Dzibilchaltun, Becán, and other northern sites. Rovner and Ball worked together to attempt to tease out some tenable cultural-historical information from the Becán lithic collection. This proved more elusive than anticipated, but a number of intriguing findings did emerge.

Most pertinent to our rehabilitation of Becán is the chronological distribution of central Mexican green obsidian within the confines of the earthwork. Telltale clear green to specular gold-sheen obsidians were quantitatively abundant. They appeared in a range of forms from simple prismatic blades and blade segments to small leaf-shape bifaces and well-made tanged dart points (Ramirez 2001; Rovner 1975; Rovner and Lewenstein 1997). All this central Mexican green obsidian came from Chacsik and terminal facet Pakluum-Chacsik contexts. Until well into the Terminal Classic tenth century none (apart from the four points found in
1969) came from any contexts dating after about A.D. $460 / 500$ when the full Middle Classic Sabucan ceramic complex abruptly replaced Chacsik at Becán. To reiterate, other than in three redeposited instances of mixed Sabucan and earlier materials, central Mexican green obsidian was relatively abundant at Becán throughout the Early Classic Chacsik phase. It vanished completely and abruptly with or during Sabucan, the cultural phase that Ball originally associated $s$ with a successful assault on and capture of Becán by Teotihuacan-affiliated Tikal/Petén forces sometime between A.D. 440 and 460 (Ball 1977a, 1979; Ramirez 2001; Irwin Rovner, personal communications 1971-1974; Rovner 1974, 1975; Rovner and Lewenstein 1997).

The overall pattern is:

(1) Central Mexican green obsidian is well-represented at Becán from terminal facet Pakluum through late facet Chacsik times (ca. A.D. 150-400/ 460).

(2) Central Mexican green obsidian is also well-represented at Tikal during its Early Classic Manik phase (ca. A.D. 250-550), after first appearing in Terminal Preclassic contexts (Moholy-Nagy 1999, 2003; MoholyNagy et al. 1984, 2013). ${ }^{31}$

\footnotetext{
${ }^{31}$ Thirty years later, Ramirez (2001), a graduate student at San Diego State University, significantly enlarged on and verified Rovner's findings in an analysis of the obsidian collection recovered by the 1973 National
} 


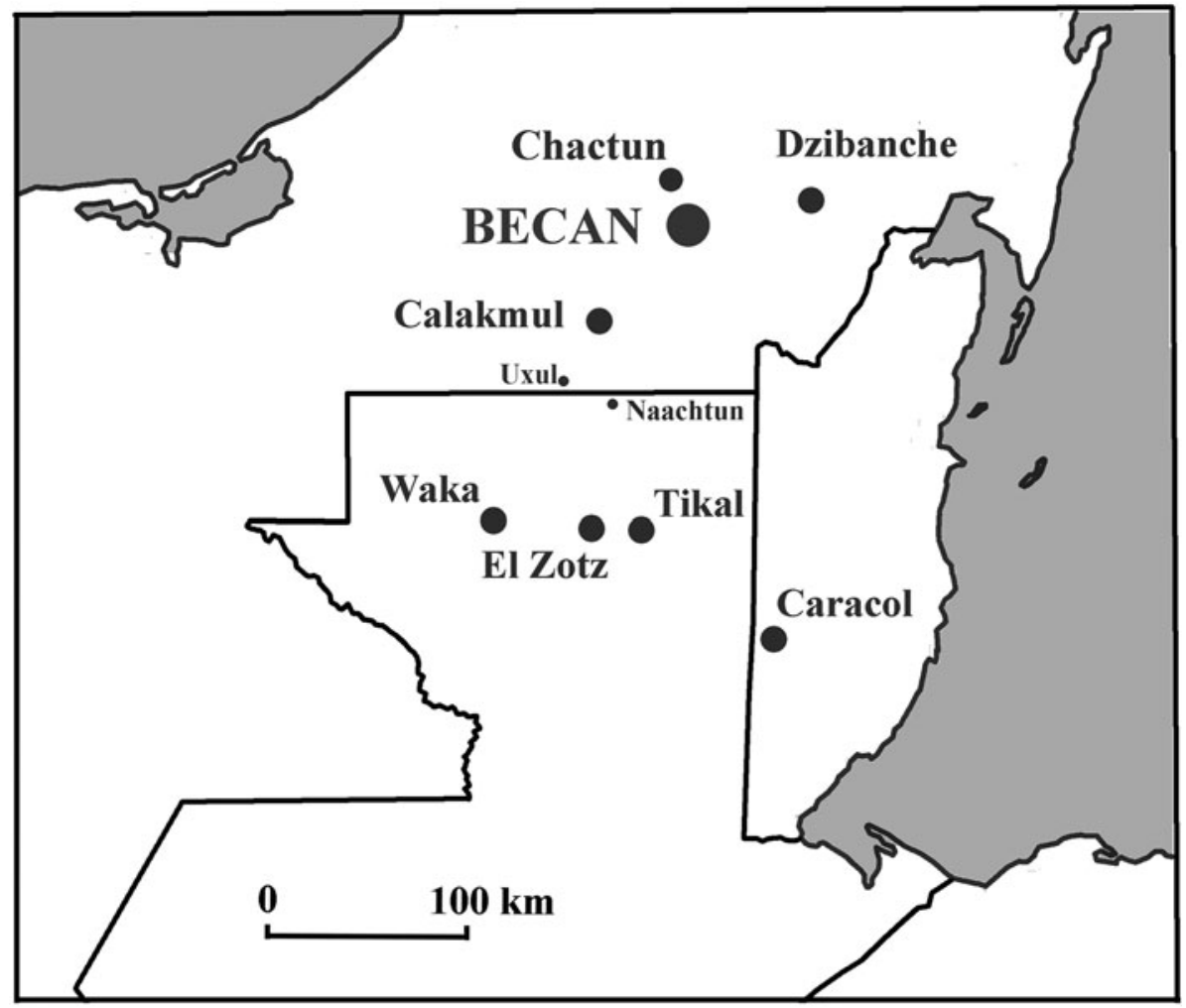

Figure 19. Becán in Snakeland. Map by the authors.

(3) Green obsidian from any source is conspicuously absent from Calakmul throughout the full Classic period (Braswell 2013; Volta et al. 2020), and clearly this commodity was unavailable to the rulers of the Kaanu'l polity, particularly during the Early Classic.

All this suggests direct interactions and commercial or other ties linking fortified Chacsik Becán to Tikal, rather than to the capitals of the Kaanu'l dynasty, Dzibanche and Calakmul, that flank it to the northeast and southwest. Braswell (in Volta et al. 2020:359-360) believes that central Mexican "green" was not commodified at this early date, and argues that its presence reflects the existence of important political and/or social ties to Tikal and thence, indirectly, to Teotihuacan, rather than any commercial interactions. Obsidian from the presumably commodified El Chayal source in Guatemala is well-represented, even abundant, from the Late Preclassic through the entire Early Classic and the following Late and Terminal Classic at Becán, Tikal, and Calakmul. It shows no signs of having been in any way restricted or otherwise difficult to obtain at any of these centers throughout the entire Classic period (Braswell 2013; Ramirez 2001; Rovner 1975; Volta et al. 2020).

Two other southern Campeche-Petén centers, Uxul and Naachtun, lie well south of Becán between Calakmul and Tikal. They have also produced large quantities of central Mexican green obsidian, seemingly restricted to high status elite contexts in both cases. Braswell omits Becán in his modeling, which is a shame because it apparently fits the pattern of the third- through fifth-century, Tikal-linked, Calakmul-opposing centers that he identifies. From this perspective,

Geographic Society-University of Wisconsin, Madison Río Bec Regional Project. the fortifications seem to reflect Becán's very precarious existence within the heart of Snake territory.

\section{Implications of Sabucan-Phase Ceramics}

Ball's (1973, 1977a, 1979) original idea of a probable north-central Petén military site-intrusion at Becán at the start of the Sabucan ceramic phase was based on the few usable ceramics studies then available. During the last three decades he has become increasingly uncomfortable with this assessment on several grounds. Chief among them was the above-mentioned sudden and complete disappearance of Mexican green obsidians coinciding with the appearance of the Sabucan ceramic assemblage (Tzakol 3-equivalent).

Sabucan deposits everywhere at Becán typically lay directly over and on Pakluum floors, sometimes with intervening soil horizons reflecting temporary abandonments. More often than not, the basal layers of these deposits constituted something of a "crush zone," with late facet Chacsik sherds inextricably mixed with Sabucan materials. Teotihuacan-style tripod cylinder vases and associated apron lids in a variety of glosswares-brown, orange, black, and bichrome-appear abruptly with Sabucan, and are restricted to it (the cache vessel in Structure XIV is a famous example). These two companion forms are generally accepted to have been connected to elite storage, movement, and presentation of raw kakaw (cacao) beans or powdered cacao.

Fragments of such vases and lids were well-represented in virtually all our recorded Sabucan deposits, but they are not uniformly strewn throughout these vertically. They are instead restricted to the lowermost $10 \mathrm{~cm}$ of the deposits, effectively the basal layer or "crush zone" of Chacsik/Sabucan intermingling. This distribution 
might reflect a temporal faceting of Sabucan based on the content of the "crush zone," with a Peténized early or "initial" Sabucan facet represented by the Chacsik-Sabucan "crush zone" and its indisputably Teotihuacanoid content, and a later facet or "full" Sabucan cleansed of such exotics and influences extending above it.

Within the thin basal, "initial" Sabucan crush layer, we in places find late facet Chacsik ceramic materials, Sabucan ceramics, green obsidian artifacts, tripod cylinders, apron lids, pieces of slate-backed pyrite mosaic mirrors, and also scattered fragments of human bone. Thicker "sanitized" Sabucan deposits continue above. We now believe that the "crush zone" represents both a relatively short-lived early or initial facet of Sabucan marked by intensified Tikal/ Teotihuacan influence or presence, and the infusion of new ceramic and other artifactual elements symbolizing the latter's post-A.D. 378 association with Teotihuacan. Just when the Tikal/ Teotihuacan political order extended to Becán is unknown, except that it occurred sometime between A.D. 400 and 562. The "sanitized," regional late facet of Sabucan persisted, ultimately blending into the Tepeu 1 horizon Bejuco assemblage.

Other insights involve surface finish and form-mode characteristics of the Sabucan complex that seem inconsistent with what we know of north-central Petén pottery. Individual, decontextualized tomb vessels from Dzibanche and Calakmul appeared sporadically and randomly in museum exhibits and coffee table art books, and Ball was struck by their often close similarities with finer Sabucan complex ceramics. This raised the possibility that Becán's Early Classic attackers were Kaanu'l dynasty forces, not Petén-related enemies. We now think it likely that the obsidian and ceramic evidence reflect strong Tikal-Teotihuacan influence, but not any sort of attack and take-over. This view contravenes Ball's earlier suggestions of a fifth-century attack on Becán by Teotihuacan-affiliated Tikal/Petén forces, but older views must and should give way to newer data.

The difficulty of verifying our alternative scenario is the absence of full, or even partial, ceramic sequences for either Dzibanche or Calakmul, despite the prominence of both centers in the archaeological literature. For Calakmul there is a preliminary ceramic study by Domínguez Carrasco (1994) based on excavations carried out by Folan for the Universidad Autónoma de Campeche in 1984-1985 and 1988-1989, but these were confined to Structures I, II, III, and VII. Her sequence is preliminary and not stratigraphicallybased, but rather typologically so, as she makes clear. Careful study of Domínguez's sequence discloses additional problems. Her chronologically floating Early Classic Kaynikte complex clearly extends no later than ca. A.D. 500/550, while her similarly floating Late Classic $\mathrm{Ku}$ complex plainly begins no earlier than around A.D. 690/700, these dates based on typology and modal diagnostics in each case. This leaves the critical period between A.D. 500 and 690/700, the era of both Calakmul's ascendancy in the Maya world and the abrupt appearance of the Sabucan complex at Becán, an unrepresented and unknown blank. Trying to fill this gap by hit-and-miss hunting through exhibit catalogues and art books for the occasional, isolated funerary vessel is unconscionable as a research strategy, but the only one available given the continuing absence of robust, full-fledged, and widely-published ceramic sequences for either of the two key Kaanu'l centers.

Pending such new ceramic insights, we suggest that Becán's early Late Classic florescence between A.D. 590/610 and 730/750 reflects likely subjection to, or alliance with, the Calakmul-Dzibanche Kaanu'l polity and a subsequently more amicable or quiescent relationship with it.
The center's rapid failure and abandonment in the first half of the eighth century might readily reflect the collapsing fortunes of the Kaanu'l polity. Throughout most of its archaeologically documented history, Becán was a pivotal crossroad on the overland transpeninsular route between the Caribbean and the Gulf of Mexico (Ball 1977a; Ball and Taschek 1989; Rovner 1974, 1975; Rovner and Lewenstein 1997), and it is inconceivable that the weakening political power and economic influence of the giant center to the southwest had no serious reverberations on Becán's economic and political fortunes and viability. We submit that this was exactly the case, and that the defeats of Calakmul in the very late seventh and early eighth centuries had devastating consequences for Bejuco-era Becán.

\section{A Testable Conjecture}

We think the preceding information boils down to this new, plausible, and testable scenario:

(1) Becan's earthwork was originally built before A.D. 200 in reaction to some unknown Late Preclassic threat or crisis.

(2) Sometime well before the "arrival of strangers" at Tikal in A.D. 378, the latter had established a peaceful commercial or political presence at Becán, whose earthwork might already have been seen as a strategic asset.

(3) In the early to middle fifth century, sometime after the "arrival of strangers," the influence and perhaps actual presence of the expanding Tikal/ Teotihuacan political order at Becán intensified significantly, ushering in the distinctive Sabucan ceramic phase. It began before we have textual evidence of the Tikal/Snake wars, suggesting earlier, unrecorded antagonisms between the fledgling "superpowers."

(4) The Becán-Petén alliance constituted both a direct tactical and strategic threat to the rising Snake rulers. Sometime late in the sixth century they successfully and violently attacked Becán and incorporated it into their local dependencies. Maintenance of the earthwork ceased, and the Snake lords could shift their base south to Calakmul without having a Petén outpost to their rear.

(5) The major decline or abandonment of Becán that Ball detected between about A.D. 730/750 and 830 coincided with the final defeat and unraveling of the Kaanu'l political order.

\section{Post-hegemonic Becán}

If the above scenario is true, the concurrent emergence of a large new center, the recently discovered Chactun, some 24 kilometers northnorthwest of Becán (Šprajc 2014, 2021) seems more than coincidental. Chactun has conspicuously strong epigraphic and architectural ties to the north-central Petén, including sculpted stelae and altars replete with glyphic texts (Esparza Olguín 2015; Šprajc 2015; Šprajc et al. 2015). Among the 20 stelae and 15 altars recorded thus far, 11 carry remnants of sculpted figures and texts, including six readable dates corresponding to A.D. 731 and 751. At least two of these monuments, Stelae 1 and 12, were dedicated on 9.16.0.0.0 2 Ajaw 13 Sek (May 5, 751) by one Aj K'ihnich Balam. Chactun quite conceivably figured into Becán's demise somehow, but whether in a consequent, causal, exploitive, or purely incidental way is unknown, pending more substantive information about the site and its history. Surface sherds and the ceramic output of the small handful of test pits excavated at the site thus far shed little to no light on this dynamic (Ball 2015, 2017; Dzul Gongora 2020). To date, we have little evidence of the occupational history of Chactun or its smaller sister sites Tamchen and Lagunita prior to the Late Classic. 


\section{The Río Bec/Chenes Regional Florescence}

To work out what happened at Becán between ca. A.D. 400 and 600 and in the mid-eighth century requires a fresh program of carefully conceived and focused investigations. The broad outline of events very probably followed the scenario laid out above. Ball believes that Becán's decline and the final defeat of Calakmul in the late seventh and eighth centuries prepared the way for a more decentralized tradition of dispersed elite groups and a thriving rural regional population. The impressive French and Slovenian surveys to the south, southeast, and north of Becán document this new settlement form (Nondédéo et al. 2013; Šprajc 1996, 1998, 2021). Interestingly, to our knowledge they have identified no obtrusive local fortifications indicating serious warfare. Neither are there signs of defensive systems such as documented around Piedras Negras/Yaxchilan or the La Buenavista regions. ${ }^{32}$ The earliest Becán-region inscriptions and iconography at A.D. 475 do depict themes of war and dynastic founding, so more fortifications might in the future be identified on recent lidar images.

In their own examination of the rise and florescence of the Río Bec regional centers, archaeologists of the 2002-2010 French Río Bec Project also considered the presence and likely impact of Calakmul and its fortunes (Nondédéo et al. 2013:50), but they arrived at a conclusion markedly different from our own (Taladoir et al. 2013). The French believe that the Río Bec florescence and population boom beginning around A.D. 550/590 and lasting until 700 were largely independent of the florescence and decline of Calakmul and Dzibanche. We find this idea difficult to accept, as did Coe (2012:140), who thought it inconceivable that Becán and other Río Bec centers were not under Calakmul's sway. The French, in contrast, perceive little, if any social or economic impact arising from the florescence or failure of Calakmul on the emergence of Río Bec society and its distinctive settlement and organizational patterns, and instead emphasize a largely autochthonous origin for the zonal tradition.

However they were affected by the Tikal/Kaanu'l struggles, the Río Bec and Chenes regions seem to have thrived after the final decline of the Calakmul order, and the landscape south of Santa Rosa Xtampak is characterized by numerous small but impressive elite groups with no local dominant central place. What these sites share is one consistent and breathtaking architectonic/iconographic theme- building façades displaying enormous, imposing, sculpted serpentine "Monster Mouth" entry portals. In 2018, Stuart remarked to Webster that the obtrusive snake-mouth or Witz monster imagery so common on the façades of Late Classic Río Bec and Chenes buildings might hark back to the time when the whole region, Becán included, was under the sway of the Snake Lords of Dzibanche and Calakmul. At Becán such portals are preserved on the front façades of the mammoth early seventh-century, Bejuco-age Structure X and early Terminal Classic Structure IV (Potter 1977). Iconographically distinct Itzam Yeh and/or Chac corner masks (e.g., on Chicanna Structure XX) are not known to occur in the area until the advent of Terminal Classic Xcocom ceramics and architecture. Just how this might relate to the late influx of northern people or influences detected by Ball is unclear. In the early to mid-ninth century the still well-populated

${ }^{32}$ Such systems often include walls, ditches, and barricades located well away from core architecture, as in the Usumacinta examples. Based on his work at Naachtun, Levia (2010) also pointed out the intrasite systemic integration of strong-points at Naachtun and elsewhere. southeastern Campeche region was infiltrated by peoples with strong northern ceramic affiliations (Ball 1973, 1977b; Ball and Taschek 2013, 2015; Thomas and Campbell 2008), and many abandoned standing buildings were selectively reoccupied by them (Thomas 1981). It was at this same time that the grand florescence of the distinctive twin-towers Río Bec style began, best represented by Becán Structure I (Bueno Cano 1999; Michelet et al. 2013).

Along with the southeastern Campeche zone generally, Becán revived after its several decades of decline or abandonment and thrived mightily during the Terminal and Early Postclassic, experiencing an architectural "boom" beginning about A.D. 830/850. This is presumably one of the reasons why our Mexican colleagues prefer a late date for the earthwork-it provided the raw material for all this construction. Unexplained by their borrow-pit hypothesis are that twothirds of the excavated material was clearly not used for this or other purposes, but simply left in place, and why almost 90 percent of all the ceramic material recovered from the ditch is of earlier Late Classic date (ca. A.D. 600-730/750). That the embankment was not ravaged for construction material suggests the defenses remained socially or militarily significant until very late. In any case, there was impressive ninth-century construction at Becán and much of its hinterland retained significant population right through A.D. 1050-1100.

\section{CLIMATE CHANGE}

Ball's 2014 reanalysis of Becán's ceramic sequence shifts attention to something else we knew nothing about in 1970 — climate change. We briefly alluded above to early humid and dry cycles, the latter conventionally called droughts. Four such Preclassic dry intervals were detected in the proxies analyzed by Ebert et al. (2017; see also Kennett et al. 2012:788). Our estimated interval for earthwork construction exactly aligns with the inception of the latest one. ${ }^{33}$ Shortly after we completed our dissertations we separately advanced hypotheses about how demography, agrarian adaptations, and warfare shaped early Maya cultural and political evolution (Ball 1977a; Webster 1977). At that time, the warfare issue was problematic for some archaeologists because Preclassic population densities were much lower than those of the Classic, and because evidence for warfare over land or for any other reason was practically non-existent. If the Preclassic dry intervals posed serious threats to early farming communities, however, they suggest density-independent motives for competition, conflict, and increased political centralization. ${ }^{34}$

More important in regard to climate change are the great panlowland droughts so conspicuous in the literature since the mid-1990s (see Iannone [2014] and Kennett and Hodell [2017] for

${ }^{33}$ Ebert et al. (2017) call these intervals "droughts," a loaded term because it presupposes that moisture is so limited as to have deleterious effects on farmers, something that might or might not be true. See Webster (2014:344-348) and Webster (2018) for commentaries on the interpretations commonly derived from various climatic proxies, and particularly how much or how little rainfall was optimal for ancient farmers. Various chapters in Iannone (2014) discuss the several meanings of the concept "drought."

${ }^{34}$ Kennett et al. (2012) assessed the relationship between climate change and conflict and concluded that multidecadal droughts beginning at the end of the Classic period led to unusual levels of conflict. They measured the intensity of conflict using warfare references in inscriptions. Although they note a dry episode at the end of the Preclassic, they are unable to relate this interval to warfare because of the absence of texts-a good example of how our perceptions and interpretations have become heavily dependent on inscriptions. Long before this article was written, we knew that there was evidence of serious warfare at least by Late Preclassic times. 
recent overviews). It is tempting to associate the whole or partial abandonment of Becán between about A.D. 780 and 830 with the onset of this dry interval. Unfortunately, Becán's ninth-century revival and apparent demographic vigor thereafter do not accord well with the proposed episodes of multidecadal drought between A.D. 850 and 1100 . The French do detect a serious demographic decline beginning around A.D. 950-1000, so the Río Bec zone was seemingly more fragile than Becán itself. Just maybe the old earthwork (not some Terminal Classic new one), helped give Becán's population an additional lease on life for several centuries. ${ }^{35}$

Becán's fortifications were built with a specific threat in mind, but one so early we will never know about it from inscriptions. Nevertheless, their scale and construction made them very durable and situationally useful for the duration of Becán's long occupational history, and not just as sources of building material. Even after maintenance ceased around A.D. 600 and in their subsequent dilapidated condition they remained much more formidable obstacles than the rickety little fortifications at Late or Terminal Classic centers such as Dos Pilas or Aguateca. Their use-life (what Arkush [2011:12] calls "landscape patrimony") thus spans many potential times of trouble extending far beyond A.D. 600 (Figure 20). Anyone who wants to propose a later date for the use of the earthwork has several options (8-10 on the list), and we suspect that the Maya saw it as both a source of security and a convenient demarcation of social/ritual space throughout Late and Terminal Classic times and into the Postclassic.

\section{SUMMARY}

Despite its undoubted early occupation, its impressive Late Preclassic earthwork and architecture, and its refined ceramic sequence, Becán still figures poorly in current accounts of early Maya civilization, just as it did in Morley's time. For example, the site is absent from the overview volume Pathways to the Past: A View from the Maya Lowlands (Brown and Bey 2018), and gets only two very brief mentions in Traxler's and Sharer's (2016) The Origins of Maya States. ${ }^{36}$ This despite the fact that the several extensive Instituto Nacional de Antropología e Historia de Mexico "intervenciones," as well as our original MARI-Tulane project, documented the presence across the center of immense Late Preclassic plazas flanked by big terraced and very probably frontally masked pyramids, including Structures IV-sub and IX-sub (Ball and Andrews 1978; Bueno Cano 1999; Campaña 2014). Perhaps these receive little attention because they are buried under later constructions.

One reason for this neglect might be the unfounded claims about the chronology and function of the earthwork, which hopefully we have finally dispelled. A second reason is that what we currently know of the early archaeological record at Becán is iconographically and symbolically undistinguished by Preclassic standards elsewhere. Unreported so far are murals such as those found at San Bartolo, the elaborate caches of Cival and Ceibal, the rich burials beneath Tikal's North Acropolis, or the E-groups so prominent in Preclassic site layouts. Structure $\mathrm{X}$ does boast at least one enormous basal terrace façade sculpture such as found at Uaxactun, Holmul, Nakbe, and El Mirador, but it is most likely of Chacsik date. Why Becán, apart from the earthwork, lacks such impressive Preclassic markers is itself an

\footnotetext{
${ }^{35}$ But not because it served as a reservoir for household use. Access to water for drinking and other household use soon becomes irrelevant if rain does not water crops.

${ }^{36}$ The Traxler and Sharer volume locates Becán in the wrong part of Mexico and also incorrectly dates the 1973 School of American Research Seminar on the "Origins of Maya Civilization" to 1974.
}

interesting issue. Part of the answer undoubtedly lies in the limited extent and intensity of the archaeology conducted at the site, and the vagaries of preservation. Five sculpted limestone stelae are known from inside the ditch and four others are immediately outside it, but all are so severely damaged and eroded as to preclude any sensible decoding of their iconography or possible texts (two of these, Stelae 1 and 2 immediately south of Structure XII, may be of Sabucan date; all others are most probably of Xcocom vintage). The many "missing" impressive bells and whistles of other Preclassic and Classic Maya centers might just reflect the contingencies of archaeology. None of this, however, detracts from Becán's importance as a regional political power and as a prominent actor in lowland events and processes. And Becán was no flash-in-the-pan place as were some other Maya centers. Its lack of readable inscriptions is counterbalanced by its longevity, now extending from the early Middle Preclassic until the twelfth century, and its impressive resilience in the face of many successive crises.

Anyone reading accounts of the great Early to Late Classic hegemonic struggles that so dominate much of the literature will find that few mention Becán even in perfunctory ways (as Coe did), much less consider in detail its potential political and military significance. In our experience, the answer is none. That a great fortified center on the scale of Copan smack in the center of Snakeland should be an orphan in all these narratives is very strange. If a single monument were found at Becán with a readable sixth- or seventhcentury date, a reference to a warfare event, or the name of a warrior-king, the site would suddenly leap to prominence in our discourse. Our rehabilitation, and especially our case study, show that even without elaborate art, dates, and inscriptions, good excavation strategy and complementary artifact analyses can suggest important cultural-historical models and hypotheses that can be tested in the future, and that ignoring Becán as a significant agent potentially creates strange gaps and distortions in our historical narratives.

For a long time Becán was significant because it was the only large center on a landscape of smaller sites that lacked inscribed and dated monuments. French and Slovene research heavily reinforces the dispersed character of settlement in southeastern Campeche detected by early twentieth-century explorers, and provides much-needed detail. The discovery of Chactun and its monuments adds another large center with inscriptions that must be integrated into our conceptions of regional settlement, population, and political history. Becán remains, however, the only known fortified place, although lidar imagery might soon document others. Its early earthwork sheltered its people through many times of trouble, including the environmental and political stresses of the Late Preclassic, the dynastic struggles of the Tikal and Kaanu'l dynasties, several intervals of climate change, the major Late/Terminal Classic droughts, and the "big" Maya collapse.

In 1970 the widely shared belief in the peaceful Classic Maya stimulated resistance to the warfare implications of the Tikal ditch and Becán's earthwork. Fifty years later we face two almost mirror-image situations. First, everyone now agrees that warfare was both early and commonplace, and that we must understand it to make sense of Maya culture history and political evolution, especially the great hegemonic struggles of the sixth through the eighth centuries. Today the Maya landscape is replete with apparent defensive features, including many of Preclassic date (see section When Was the Earthwork Built?) that are among the biggest-known anywhere. Numerous apparent fortifications are being revealed (e.g., Canuto et al. 2018; Garrison and Houston 2018a). Given the high visibility of warfare in the literature, archaeologists are tempted to reflexively identify many newly discovered landscape features as having defensive functions. Many of 


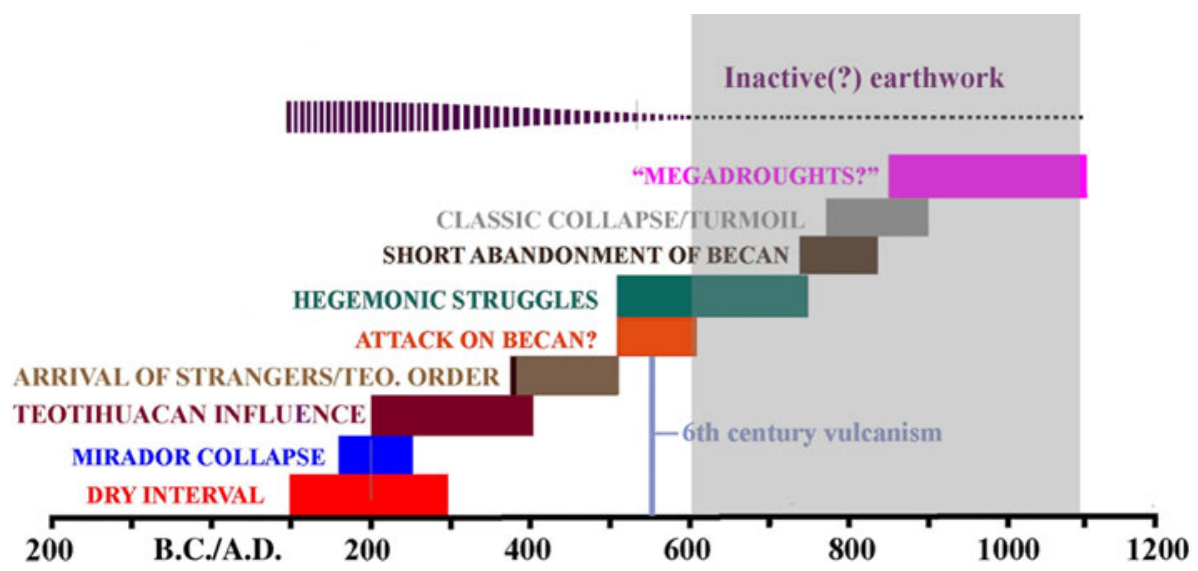

Figure 20. Times or intervals of plausible instability or crisis at Becán juxtaposed with interval of non-maintenance of the earthwork. Image by the authors.

them, like Becán's, will be essentially ahistorical because they are too early, because they lack ground-truthing, or because they have few or no associated texts. ${ }^{37}$ As the debates about Becán show, it is very difficult to date ditches, walls, and embankments, and to be certain about their functions and their wider cultural-historical implications. The Becán earthwork is just about the most self-evident defensive construction imaginable, yet many doubted (and some still do) both its function and its antiquity. The cautionary tale is that newly discovered landscape features, especially putative defensive ones, require focused groundwork, and even a certain amount of serendipity, to ascertain what they are, when they were built and used, and what they mean.

The second mirror-image situation is a methodological one. For Becán we have a highly refined ceramic sequence unassociated with texts of any kind, while at Calakmul and Dzibanche we have inscribed dates and inscriptions, but no adequate ceramic sequences. We can do little to correct the first deficiency, but much to correct the second. Inscription-based interpretations, along with those derived from complex iconography, increasingly dominate our perceptions of the Classic and Preclassic, but they can never and should never displace sound anthropological field archaeology as a primary approach to elucidating ancient Maya civilization. ${ }^{38}$ We hope we have shown that revisiting old research in light of new finds can reveal significant, unexpected, and testable possibilities.

We finish with an astronomical analogy. Gravitational effects of unseen celestial objects on visible ones for centuries have led astronomers to fundamental discoveries. Becán is big star in our constellation of Maya centers, but not a bright one because it is dimmed by the haze of ahistoricity. ${ }^{39}$ Nevertheless, in its day Becán had abundant sociopolitical, demographic, and military gravity during the turbulent times of the Late Preclassic, the following hegemonic conflicts, and through and beyond the Classic collapse. By paying more attention to it we might detect unsuspected wobbles in the careers of many great contending polities, especially those so brightly illuminated by Classic inscriptions and dates.

\section{RESUMEN}

Una investigación realizada en 1970 por el Middle American Research Institute (MARI) de la Universidad de Tulane hizo que Becán se destacara en el paisaje de los grandes centros mayas. El Proyecto Becán en realidad se desarrolló de 1969 a 1971 bajo los auspicios de MARI y la dirección de E. Wyllys "Bill" Andrews IV y Richard E. W. Adams de la Universidad de Minnesota con el apoyo de la National Geographic Society y la Fundación Ford, y la amable autorización del Instituto Nacional de Antropología e Historia de México. El trabajo de campo continuó en 1973 bajo la dirección de Adams, siendo las instituciones participantes ese año la Universidad de Wisconsin y la Universidad de Tennessee bajo la dirección separada de Prentice M. Thomas, Jr. Sin embargo, fue en 1970 cuando el mapeo intensivo, excavación, y la estratigrafía cerámica reveló que el enigmático trabajo de tierras de Becán, por primera vez en 1934, era una fortificación de gran antigüedad, construida en el preclásico muy tardío, a finales del siglo II d.C. La guerra a gran escala resultó

${ }^{37}$ Webster (1978) tested three such ahistorical fortified centers in northern Yucatan.

${ }^{38}$ Most practicing Mayanists today have been immersed in data from inscriptions throughout their careers. The authors, by contrast, belong to the last generation of archaeologists who were educated and came of professional age during the antediluvian days when we understood dates, but had only a dim appreciation of other glyphs, mainly emblem glyphs. inesperadamente tener raíces muy profundas en las tierras bajas mayas. Sin embargo, las implicaciones histórico-culturales más amplias de Becán permanecieron en gran parte oscuras por la ausencia de fechas glíficas u otras inscripciones, y la creciente dependencia de los arqueólogos mayanistas de la información textual-histórica e iconografía. Lamentablemente, esto marginó el sitio en las narrativas mayanistas. Varios arqueólogos incluso afirmaron que interpretamos incorrectamente tanto la naturaleza de los movimientos de tierra (no una fortificación sino un suministro de agua, una sistema de control de agua o una cantera de piedra) como su datación (no el preclásico sino el clásico terminal). Su trabajo, sin embargo, identificó el hecho de que Becán había tenido apogeos no solo en el preclásico tardío y la primera mitad del clásico tardío, sino también en el clásico terminal de los siglos IX y X. En este artículo, rehabilitamos Becán disipando estas afirmaciones y mostrando que la evidencia arqueológica tradicional, contextualizada en lo que conocemos hoy, tiene mucho que decir sobre el papel del sitio en la historia de la cultura de las tierras bajas. Identificamos intervalos de crisis en los que los movimientos de tierra defensivos hubiera sido útiles, especialmente durante las grandes luchas hegemónicas entre las dinastías Dzibanche-Calakmul Kaanu'l y Tikal. Además, presentamos "nuevos" datos líticos y cerámicos antiguos relacionados con la historia de

\footnotetext{
${ }^{39}$ There are other such centers in Mesoamerica-Cantona in central Mexico is an example.
} 
los asentamientos y las relaciones políticas de Becán. Un nuevo examen de las variaciones temporales y espaciales en las distribuciones de obsidianas "grises" y "verdes" y artefactos de obsidiana en Becán, Calakmul y Tikal proporciona una fuerte evidencia sobre las afinidades sociopolíticas de Becán durante los siglos II al V, y quiénes son los conquistadores de Becán en el siglo V a principios del VI d.C. El florecimiento del centro en el siglo VII y principios del VIII y el repentino fracaso y abandono a mediados del siglo VIII también se aclaran con nuestra rehabilitación de datos de hace cincuenta años. Nuestro mensaje más importante, sin embargo, es que las inscripciones, con todo su dramático detalle cronológico y su agencia histórica, siempre deben complementarse con el trabajo de campo y el trabajo de laboratorio tradicionales.

\section{ACKNOWLEDGMENTS}

We thank the Middle American Research Institute at Tulane University, the National Geographic Society, and the Ford Foundation for their support of our Becán research. Both the University of Minnesota and the University of Wisconsin provided additional logistical and funding resources. E. Wyllys Andrews IV deserves to be lauded for his remarkable foresight regarding Becán's potential importance. Richard E. W. Adams, project codirector, recruited both of us for the 1970 effort. Many other colleagues provided encouragement and guidance, as did our splendid local workers. Eduardo Torres Sanchez, the project ceramic technician and lab supervisor, rendered invaluable service behind the scenes. We especially thank the Instituto Nacional de Antropología e Historia de México and the Centro Regional del Sureste and their successive directors for permission to conduct fieldwork at

\section{REFERENCES}

\section{Arkush, Elizabeth}

2011 Hillforts of the Ancient Andes: Collab Warfare, Society, and Landscape. University of Florida Press, Gainesville.

Armillas, Pedro

1951 Mesoamerican Fortifications. Antiquity 25:77-86.

Ball, Joseph

1971 A Preliminary Report on the Ceramic Sequence at Becán, Campeche, Mexico. Cerámica de Cultura Maya 7:16-30.

1973 Ceramic Sequence at Becán, Campeche, Mexico. Unpublished Ph.D. dissertation, Department of Anthropology, University of Wisconsin, Madison.

1974 A Teotihuacan-style Cache from the Maya Lowlands. Archaeology 27:2-9.

1976 Ceramic Evaluations. In The Fortifications of Becán, edited by David Webster, pp. 121-130. Middle American Research Institute Publication 41. Tulane University, New Orleans.

1977a The Archaeological Ceramics of Becán, Campeche, Mexico. Middle American Research Institute Publication 43. Tulane University, New Orleans.

1977b The Rise of the Northern Maya Chiefdoms. In Origins of Maya Civilization, edited by Richard E. W. Adams, pp. 101-132. University of New Mexico Press, Albuquerque.

1979 Southeastern Campeche and the Mexican Plateau: Early Classic Contact Situations. In Actes du XLIIe Congres International des Americanistes, Vol. VIII, pp. 271-280. Fondation Singer-Polignac, Paris.

2014 Rethinking the Becán Ceramic Sequence. Latin American Antiquity 25:427-448.

2015 Surface Ceramics from Lagunita and Tamchén, Campeche-A Report on Materials Recovered during the 2014 Field Season of the Slovenian Academy of Sciences and Arts Research Center Archaeological Reconnaissance Project in Southeastern Campeche. In Reconocimiento Arqueológico en el Sureste de Campeche, temporada 2014. Informe técnico, Consejo de Arqueología, Instituto Nacional de Antropología e Historia de México, edited by Ivan Šprajc, pp. 37-51. Slovenian Academy of Sciences and Arts Research Center, Ljubljana.

2017 Ceramics and Lithics. In Paisaje arqueológico y dinámica cultural en el área de Chactún, Campeche (2016-2018): Informe de la temporada 2017, edited by Ivan Šprajc, pp. 68-90. Centro de Investigaciones de la Academia Eslovena de Ciencias y Artes, Ljubljana.

2021 Surface Ceramics from Lagunita, Tamchén, and Chactún, Campeche, México. In Archaeological Reconnaissance in Eastern Campeche: Chactún, Tamchén, Lagunita, edited by Ivan Šprajc, pp. 43-59, 113-132. Middle American Research Institute Publication 73. Tulane University, New Orleans.

Ball, Joseph, and Jennifer Taschek

1989 Teotihuacan's Fall and the Rise of the Itzá: Realignments and
Becán and for their unobtrusive and effective oversight of our work. We are also indebted to the French and Slovene archaeologists whose work has recently revealed so much about southern Campeche that we did not know in 1970. Long ago the authors received permission from the National Geographic Society to use any Becán project images in their publications and research. The photo archive is now administered by the Middle American Research Institution at Tulane University, whose successive directors have been similarly generous with permission. Most Becán images used here are either from the authors' personal collections or were created by them. Several others were graciously provided by colleagues identified in the captions. Comments from several perceptive reviewers also helped us refine our article.

Role Changes in the Terminal Classic Maya Lowlands. In Mesoamerica after the Decline of Teotihuacan, AD 700-900, edited by Richard Diehl and Janet Berlo, pp. 187-200. Dumbarton Oaks Research Library and Collections, Washington, DC.

2013 Acanmul, Becán, and the Xcocom Phenomenon through a Type Variety Looking Glass: Resolving Historical Enigmas through Hands-On Typological Assessments. In Ancient Maya Pottery: Classification, Analysis, and Interpretation, edited by James J. Aimers, pp. 142-162. University Press of Florida, Gainesville.

2015 Ceramic History, Ceramic Change, and Architectural Sequence at Acanmul, Campeche: A Local Chronical and its Tegional Implications. Ancient Mesoamerica 26:233-273.

Ball, Joseph W., and E. Wyllys Andrews V

1978 Preclassic Architecture at Becán, Campeche, Mexico, Occasional Papers No. 3. Middle American Research Institute, Tulane University, New Orleans.

Benevides, Antonio

2005 Campeche Archaeology at the Turn of the Century. Anthropological Notebooks. Slovene Anthropological Society 11:13-30.

Braswell, Geoffrey F.

2013 Ancient Obsidian Procurement and Production in the Petén Campechano: Uxul and Calakmul During the Early Classic to Terminal Classic Periods. Indiana 30:149-171.

Brown, M. Kathryn, and George J. Bey III (editors)

2018 Pathways to Complexity: A View From the Maya Lowlands. University of Florida Press, Gainesville.

Bueno Cano, Ricardo

1999 Entre un río de robles, un acercamiento a la arqueología de la región RíoBec. Colección Científica 411. Instituto Nacional de Antropología e Historia, Mexico City.

Campaña, Luz Evelia

2005 Contribuciones a la historia de Becán. Arqueologia Mexicana 75: 68-55.

2014 Becán: "Barranca o Cañón Formado por Agua." In Great Maya Cities of Campeche: Homage to Román Piña Chan, edited by Antonio Benavides Castillo, pp. 120-145. Turner Publicaciones, Madrid.

Canuto, Marcello A,, Francisco Estrada-Belli, Thomas G. Garrison,

Stephen D. Houston, Mary Jane Acuña, Milan Kováč, Damien Marken,

Philippe Nondédéo, Luke Auld-Thomas, Cyril Castanet, David Chatelain,

Carlos R. Chiriboga, Tomáš Drápela, Tibor Lieskovský, Alexandre

Tokovinine, Antolín Velasquez, Juan C. Fernández-Díaz, and Ramesh Shrestha

2018 Ancient Lowland Maya Complexity as Revealed by Airborne Laser Scanning of Northern Guatemala. Science 361:1-17.

Coe, Michael

2012 Royal Cities of the Ancient Maya. Thames and Hudson, New York. 
Cortes, Marisol Rincon

2007 A Comparative Study of Fortification Developments throughout the Maya Region and Implications of Warfare. Unpublished Ph.D. dissertation, Department of Anthropology, University of Texas, Austin.

Dahlin, Bruce, and Arlen Chase

2014 A Tale of Three Cities: Effects of the AD 536 Event in the Lowland Maya Heartland. In The Great Maya Droughts in Cultural Context, edited by Gyles Iannone, pp. 127-156. University of Colorado Press, Boulder.

de Périgny, Maurice

1909 Villes Mortes de l'Amerique Central. In Le Tour du Monde, Vol. 15, Nos. 38-40, pp. 445-480 Nouvelle Serie, Paris.

Domínguez Carrasco, María del Rosario

1994 Calakmul, Campeche: Un análisis de la cerámica. Colección: Arqueología. Universidad Autónoma de Campeche, Campeche.

Dull, Robert, John Southam, Steffen Kutterhoff, Kevin Anchukaitis, Armin Freundt, David Wahl, Payson Sheets, Paul Amaroli, Walter Hernandez,

Michael Wiemann, and Clive Oppenheimer

2019 Radiocarbon and Geologic Evidence Reveal Ilopango Volcano as Source of the Colossal 'Mystery' Eruption of 539/40 CE. Quaternary Science Reviews 222:105855.

Dunning, Nicholas, David Wahl, Timothy Beach, John Jones, Sheryl

Luzzadder-Beach, and Carmen McCane

2014 The End of the Beginning: Environmental Instability and Human Response in the Late Preclassic East-Central Yucatan Peninsula. In The Great Maya Droughts, edited by Gyles Iannone, pp. 107-126. University of Colorado Press, Boulder.

Dzul Gongora, Sara

2020 Análisis del material cerámico. In Paisaje arqueológico y dinámica cultural en el área de Chactún, Campeche (2016-2018): Informe de la temporada 2018, edited by Ivan Šprajc, pp. 124-159. Centro de Investigaciones de la Academia Eslovena de Ciencias y Artes, Ljubljana.

Ebert, Claire, Nancy May, Brendan Culleton, Jaime Awe, and Douglas

Kennett

2017 Regional Responses to Drought during the Formation and Decline of Preclassic Maya Societies. Quaternary Science Reviews 173:211-235.

Esparza Olguín, Octavio Q.

2015 Documentación de los monumentos esculpidos. In Exploraciones arqueológicas en Chactún, Campeche, México, edited by Ivan Šprajc, pp. 41-84. Inštitut za antropološke in prostorske študije, ZRC SAZU, Ljubljana.

Estrada-Belli, Francisco

2011 The First Maya Civilization. Routledge, London and New York.

Garrison, Thomas, and Stephen Houston

2018a Fortresses, Refuges, and Surveillance: Reconsidering the Pervasiveness of Maya Warfare. Paper presented at the 15th Annual Tulane Maya Symposium, New Orleans.

Garrison, Thomas, and Stephen Houston (editors)

2018b An Inconstant Landscape: The Maya Kingdom of El Zotz Guatemala. University of Colorado Press, Louisville.

Guenter, Stanley

2002 Under a Falling Star: The Hiatus at Tikal. Master's thesis, Faculty of Social Sciences, La Trobe University, Bundoora.

Haviland, William

2003 Settlement, Society, and Demography of Tikal. In Tikal: Dynasties, Foreigners, and Affairs of State, edited by Jeremy A. Sabloff, pp. 111-142. School of American Research Press, Santa Fe.

Houston, Stephen

1993 Hieroglyphs and History at Dos Pilas. University of Oklahoma Press, Norman.

Iannone, Gyles (editor)

2014 The Great Maya Droughts in Cultural Context. University of Colorado Press, Boulder.

Kennett, Douglas, and David Hodell

2017 AD 750-1100 Climate Change and Critical Transitions in Maya Sociopolitical Networks. In Megadrought and Collapse, edited by Harvey Weiss, pp. 205-230. Oxford University Press, New York.

Kennett, Douglas, Sebastian Breitenbach, Valorie Aquino, Yemane Asmerom, Jaime Awe, James Baldini, Patrick Bartlein, Brendon Culleton, Claire Ebert, Christopher Jazwa, Martha Macri, Norbert Marwan, Victor Polyak, Keith Prufer, Harriet Ridley, Harold Socemann, Bruce

Winderhalder, and Gerald Haug

2012 Development and Disintegration of Maya Political Systems in Response to Climate Change. Science 338:788-791.
Kosakowsky, Laura

1987 Preclassic Pottery at Cuello, Belize. Anthropological Papers of the University of Arizona. University of Arizona Press, Tucson.

Kosakowsky, Laura, Kerry Sagebiel, and Duncan Pring

2018 Long Ago But Not Forgotten: The Early Swasey Sphere of Northern Belize. Research Reports in Belizean Archaeology 15: 131-140.

Levia, Ernesto Arredondo

2010 Archaeological Investigations of a Walled Compound at Naachtun, Petén, Guatemala: Architecture, Politics, and Warfare. Unpublished Ph.D. dissertation, School of Historical and European Studies, Latrobe University, Bundoora.

Martin, Simon

2020 Ancient Maya Politics: A Political Anthropology of the Classic Period 150-900 CE. Cambridge University Press, New York.

Martin, Simon, and Nikolai Grube

1995 Maya Superstates. Archaeology 48:41-46.

2008 Chronicle of the Maya Kings and Queens: Deciphering the Dynasties of the Ancient Maya. 2nd ed. Thames and Hudson, New York.

Merwin, Raymond E.

1913 The Ruins of the Southern Part of the Peninsula of Yucatan, with Special Reference to their Place in the Maya Area. Description of the Peabody Museum Expedition of 1912. Manuscript on file at Dumbarton Oaks Research Library and Collection, Washington, DC.

Michelet, Dominique, Philippe Nondédéo, Julie Patrois, Céline Gillot, and Emyly Gillot Gómez

2013 Structure 5N2 ("Group A”): A Río Bec Paradigmatic Palace? Ancient Mesoamerica 24:415-431.

Moholy-Nagy, Hattula

1999 Mexican Obsidian at Tikal, Guatemala. Latin American Antiquity 10:300-313.

2003 The Artifacts of Tikal: Utilitarian Artifacts and Unworked Material. Tikal Reports No. 27, Part B. University of Pennsylvania Museum of Archaeology and Anthropology, Philadelphia.

Moholy-Nagy, Hattula, Frank Asaro, and Fred H. Stross

1984 Tikal Obsidian: Sources and Typology. American Antiquity 49: $104-117$.

Moholy-Nagy, Hattula, James Meierhoff, Mark Golitko, and Caleb Kestle

2013 An Analysis of pXRF Obsidian Source Attributions from Tikal, Guatemala. Latin American Antiquity, 24:72-97.

Morley, Sylvanus. G.

1946 The Ancient Maya. Stanford University Press, Stanford.

Nondédéo, Philippe, M. Charlotte Arnauld, and Dominique Michelet

2013 Río Bec Settlement Patterns and Local Sociopolitical Organization. Ancient Mesoamerica 24:373-396.

Pollock, Harry E.D.

1965 Architecture of the Maya Lowlands. In Handbook of Middle American Indians, Vol. 2, edited by Gordon R. Willey, pp. 378-440. University of Texas Press, Austin.

Potter, David

1977 Maya Architecture of the Central Yucatan Peninsula, Mexico. Middle American Research Institute Publication 44. Tulane University, New Orleans.

Puleston, Dennis, and Donald Callender

1967 Defensive Earthworks at Tikal. Expedition 9(30):40-48.

Ramirez, Robert S.

2001 An Analysis of Obsidian Artifacts from Becán Campeche, Mexico. Master's thesis, Department of Anthropology, San Diego State University, San Diego.

Rovner, Irwin

1974 Implications of the Lithic Sequence at Becán. In Preliminary Reports on Archaeological Investigations in the Rio Bec Area, Campeche, Mexico, edited by Richard E.W. Adams, pp. 103-146. Middle American Research Institute Publication 31. Tulane University, New Orleans.

1975 Lithic Sequences from the Maya Lowlands. Unpublished Ph.D. dissertation, Department of Anthropology, University of Wisconsin, Madison.

Rovner, Irwin, and Suzanne Lewenstein

1997 Maya Stone Tools of Dzibilchaltún, Yucatan, and Becán and Chicanna, Campeche. Middle American Research Institute Publication No. 65. Tulane University, New Orleans. 
Ruppert, Karl, and John H. Denison, Jr.

1943 Archaeological Reconnaissance in Campeche, Quintana Roo, and Petén. Carnegie Institution of Washington Publication No. 543. Carnegie Institution of Washington, Washington, DC.

Scherer, Andrew, and Charles Golden

2018 Early Fractured Lands: War in the Kingdoms of Piedras Negras and Yaxchilan. Paper presented at the 15th Annual Tulane Maya Symposium, New Orleans.

Simmons, Michael, Prentice Thomas, Jr., and Newel Wright

1969 Test Pitting and Minor Excavations at Becán and Chicanná, Campeche, 1969. Unpublished field and lab notes on file with Middle American Research Institute, Mérida, and Tulane University, New Orleans.

Smith, Victoria, Antonio Costa, Gerardo Aguirre-Díaz, Dario Pedrazzi, Andrea Scifoe, Gill Plunkett, Mattieu Poret, Pierre-Yves Tournigand, Dan Miles, Michael W. Dee, Joseph R. McConnell, Ivan Sunyé-Puchol, Pablo

Dávila Harris, Michael Sigl, Jonathan R. Pilcher, Nathan Chellman, and

Eduardo Gutiérrez

2020 The Magnitude and Impact of the 431 CE Tierra Blanca Joven Eruption of Ilopango, El Salvador. Proceedings of the National Academy of Sciences 117(42):26061-26068.

Šprajc, Ivan

1996 Proyecto de Reconocimiento arqueológico en el sureste del estado de Campeche, como parte de las funciones del Instituto Nacional de Antropología e Historia de México en el procede informe de la temporada julio-agosto de 1996. Centro de Investigaciones Científicas de la Academia Eslovena de Ciencias y Artes, Ljubljana.

1998 Proyecto de Reconocimiento arqueológico en el sureste del estado de Campeche, como parte de las funciones del Instituto Nacional de Antropología e Historia de México en el procedes informe de la temporada julio-agosto de 1998. Centro de Investigaciones Científicas de la Academia Eslovena de Ciencias y Artes, Ljubljana.

2014 Reconocimiento Arqueológico en el Sureste de Campeche: Informe de la Temporada 2014. Centro de Investigaciones Científicas de la Academia Eslovena de Ciencias y Artes, Ljubljana.

2020 Lost Maya Cities. Texas A\&M University Press, College Station. Šprajc, Ivan (editor)

2015 Exploraciones arqueológicas en Chactún, Campeche, México. Inštitutza antropološke in prostorske študije, ZRC SAZU. Založba ZRC, Ljubljana.

2021 Archaeological Reconnaissance in Eastern Campeche: Chactún, Tamchén, Lagunita. Middle American Research Institute Publication 73. Tulane University, New Orleans.

Šprajc, Ivan, Octavio Esparza Olguín, Arianna Campiani, Atasta Flores

Esquivel, Aleš Marsetič, and Joseph W. Ball

2015 Chactún, Tamchén y Lagunita: Tres ciudades mayas en el oriente de Campeche. Arqueología Mexicana 23:20-25.

\section{Stuart, David}

2000 "The Arrival of Strangers": Teotihuacan and Tollan in Classic Maya History. In Mesoamerica's Classic Heritage, edited by David Carrasco, pp. 465-513. University of Colorado Press, Boulder.

Taladoire, Eric, Sara Dzul, Philippe Nondédéo, and Mélanie Fornéc

2013 Chronology of the Río Bec Settlement and Architecture. Ancient Mesoamerica 24:353-372.

Thomas, Prentice M., Jr.

1981 Prehistoric Maya Settlement Patterns at Becán, Campeche, Mexico. Middle American Research Institute Publication 45. Tulane University, New Orleans.
Thomas, Prentice M., and L. Janice Campbell

2008 Excavations at Río Bec Group B, Structure 6N-1, Campeche, Mexico. Estudios de Cultura Maya 31:123-148.

Thompson, J. Eric S.

1954 The Rise and Fall of Maya Civilization. University of Oklahoma Press, Norman.

Traxler, Loa, and Robert Sharer (editors)

2016 The Origins of Maya States. University of Pennsylvania Museum of Archaeology and Anthropology, Philadelphia.

Turner, Billy Lee, II

1974 Prehistoric Intensive Agriculture in the Mayan Lowlands. Science 195:118-124

1983 Once Beneath the Forest: Prehistoric Terracing in the Rio Bec Region of the Maya Lowlands. Westview Press, Boulder.

Vogeler, Ingolf

1974 The Cultural Ecological Setting of Southeastern Campeche. In Preliminary Reports on Archaeological Investigations in the Rio Bec Area, Campeche, Mexico, edited by Richard E.W. Adams, pp. 110-112. Middle American Research Institute Publication 31. Tulane University, New Orleans.

Volta, Beniamino, Joel D. Gunn, William J. Folan, and Geoffrey F. Braswell 2020 The Political Geography of Long-Distance Exchange in the Elevated Interior of the Yucatan Peninsula. In The Real Business of Ancient Maya Economies: From Farmers' Fields to Rulers' Realms, edited by Marilyn Masson, David A. Freidel, and Arthur Demarest, pp. 352-367. University Press of Florida, Gainesville

Webster, David

1972 Defensive Earthworks at Becán, Campeche, Mexico. Unpublished Ph.D. dissertation, Department of Anthropology, University of Minnesota, Minneapolis.

1976 Defensive Earthworks at Becán, Campeche, Mexico. Middle American Research Institute Publication 46. Tulane University, New Orleans.

1977 Warfare and the Evolution of Maya Civilization. In Origins of Maya Civilization, edited by Richard E. W. Adams, pp. 335-373. University of New Mexico Press, Albuquerque.

1978 Three Walled Sites of the Northern Maya Lowlands. Journal of Field Archaeology 5:375-390.

1996 Una ciudad maya fortificada: Becán, Campeche. Arqueologia Mexicana 3:32-35.

2014 Maya Drought and Niche Inheritance. In The Great Maya Droughts, edited by Gyles Iannone, pp. 333-358. University of Colorado Press, Boulder.

2018 The Population of Tikal: Implications for Maya Demography. Paris Monographs in American Archaeology No. 49. Archaeopress, Oxford University.

Webster, David, and Jennifer Kirker

1995 Too Many Maya, Too Few Buildings: Investigating Construction Potential at Copán, Honduras. Journal of Anthropological Research 51:363-387.

Webster, David, Jay Silverstein, Timothy Murtha, Horacio Martinez, and Kirk Straight

2004 The Tikal Earthworks Revisited. Occasional Papers in Anthropology No. 28. The Pennsylvania State University, University Park.

Webster, David, Tim Murtha, Jay Silverstein, Horacio Martinez, Richard Terry, and Richard Burnett

2007 The Tikal Earthworks Revisited. Journal of Field Archaeology 32: 41-64. 